DiRECTEURS DE LA PUBLICATION / PUBLICATION DIRECTORS:

Bruno David, Président du Muséum national d'Histoire naturelle

Étienne Ghys, Secrétaire perpétuel de l'Académie des sciences

RÉDACTEURS EN CHEF / EDITORS-IN-CHIEF: Michel Laurin (CNRS), Philippe Taquet (Académie des sciences)

AssistANTE DE RÉDACTION / AssistANT EDITOR: Adenise Lopes (Académie des sciences; cr-palevol@academie-sciences.fr)

MISE EN PAGE / PAGE LAYOUt: Audrina Neveu (Muséum national d'Histoire naturelle; audrina.neveu@mnhn.fr)

RÉVISIONS LINGUISTIQUES DES TEXTES ANGLAIS / ENGLISH LANGUAGE REVISIONS: Kevin Padian (University of California at Berkeley)

RÉDACTEURS ASSOCIÉS / ASSOCIATE EDITORS ( ${ }^{*}$, took charge of the editorial process of the article/a pris en charge le suivi éditorial de l'article):

Micropaléontologie/Micropalaeontology

Maria Rose Petrizzo (Università di Milano, Milano)

Paléobotanique/Palaeobotany

Cyrille Prestianni (Royal Belgian Institute of Natural Sciences, Brussels)

Métazoaires/Metazoa

Annalisa Ferretti (Università di Modena e Reggio Emilia, Modena)

Paléoichthyologie/Palaeoichthyology

Philippe Janvier (Muséum national d'Histoire naturelle, Académie des sciences, Paris)

Amniotes du Mésozoïque/Mesozoic amniotes

Hans-Dieter Sues (Smithsonian National Museum of Natural History, Washington)

Tortues/Turtles

Juliana Sterli (CONICET, Museo Paleontológico Egidio Feruglio, Trelew)

Lépidosauromorphes/Lepidosauromorphs

Hussam Zaher (Universidade de São Paulo)

Oiseaux/Birds

Eric Buffetaut (CNRS, École Normale Supérieure, Paris)

Paléomammalogie (mammifères de moyenne et grande taille)/Palaeomammalogy (large and mid-sized mammals)

Lorenzo Rook (Università degli Studi di Firenze, Firenze)

Paléomammalogie (petits mammifères sauf Euarchontoglires)/Palaeomammalogy (small mammals except for Euarchontoglires)

Robert Asher (Cambridge University, Cambridge)

Paléomammalogie (Euarchontoglires)/Palaeomammalogy (Euarchontoglires)

K. Christopher Beard (University of Kansas, Lawrence)

Paléoanthropologie/Palaeoanthropology

Roberto Macchiarelli (Université de Poitiers, Poitiers)

Archéologie préhistorique/Prehistoric archaeology

Marcel Otte* (Université de Liège, Liège)

RÉFÉRÉS / REVIEWERS: https://sciencepress.mnhn.fr/fr/periodiques/comptes-rendus-palevol/referes-du-journal

COUVERTURE / COVER:

Archaeological works at the entrance of Cova Eirós. Photo: X.P. Rodríguez-Álvarez.

Comptes Rendus Palevol est indexé dans / Comptes Rendus Palevol is indexed by:

- Cambridge Scientific Abstracts

- Current Contents ${ }^{\circledR}$ Physical

- Chemical, and Earth Sciences ${ }^{\circledR}$

- ISI Alerting Services ${ }^{\circledR}$

- Geoabstracts, Geobase, Georef, Inspec, Pascal

- Science Citation Index ${ }^{\circledR}$, Science Citation Index Expanded ${ }^{\circledR}$

- Scopus ${ }^{\circledR}$.

Les articles ainsi que les nouveautés nomenclaturales publiés dans Comptes Rendus Palevol sont référencés par / Articles and nomenclatural novelties published in Comptes Rendus Palevol are registered on:

- ZooBank ${ }^{\circledR}$ (http://zoobank.org)

Comptes Rendus Palevol est une revue en flux continu publiée par les Publications scientifiques du Muséum, Paris et l'Académie des sciences, Paris Comptes Rendus Palevol is a fast track journal published by the Museum Science Press, Paris and the Académie des sciences, Paris

Les Publications scientifiques du Muséum publient aussi / The Museum Science Press also publish:

Adansonia, Geodiversitas, Zoosystema, Anthropozoologica, European Journal of Taxonomy, Naturae, Cryptogamie sous-sections Algologie, Bryologie, Mycologie.

L'Académie des sciences publie aussi / The Académie des sciences also publishes:

Comptes Rendus Mathématique, Comptes Rendus Physique, Comptes Rendus Mécanique, Comptes Rendus Chimie, Comptes Rendus Géoscience, Comptes Rendus Biologies.

Diffusion - Publications scientifiques Muséum national d'Histoire naturelle

CP 41 - 57 rue Cuvier F-75231 Paris cedex 05 (France)

Tél. : 33 (0)1 40794805 / Fax: 33 (0)1 40793840

diff.pub@mnhn.fr / https://sciencepress.mnhn.f

Académie des sciences, Institut de France, 23 quai de Conti, 75006 Paris.

(C) Publications scientifiques du Muséum national d'Histoire naturelle / @ Académie des sciences, Paris, 2021

ISSN (imprimé / print): 1631-0683/ ISSN (électronique / electronic): 1777-571X 


\title{
Between two worlds: Cova Eirós and the Middle-Upper Palaeolithic transition in NW Iberia
}

\author{
Arturo de LOMBERA-HERMIDA \\ Grupo de Estudos para a Prehistoria do Noroeste Ibérico-Arqueoloxía, \\ Antigüidade e Territorio (GEPN-AAT), Dpto. Historia, \\ Universidade de Santiago de Compostela (Spain) \\ arturode.lombera@usc.es (corresponding author) \\ Xose-Pedro RODRÍGUEZ-ÁLVAREZ \\ Universitat Rovira i Virgili, Departament d'Història \\ i Història de l'Art, Tarragona (Spain) \\ and Institut Català de Paleoecologia Humana i Evolució Social \\ (IPHES-CERCA), Tarragona (Spain) \\ Alicia AMEIJENDA IGLESIAS \\ Mikel DÍAZ RODRÍGUEZ \\ Grupo de Estudos para a Prehistoria do Noroeste Ibérico-Arqueoloxía, \\ Antigüidade e Territorio (GEPN-AAT), Dpto. Historia, \\ Universidade de Santiago de Compostela (Spain) \\ Iván REY-RODRÍGUEZ \\ HNHP UMR 7194, CNRS / Muséum National d'Histoire Naturelle / \\ UPVD / Sorbonne Universités, Paris (France) \\ and Sezione di Scienze Preistoriche e Antropologiche, \\ Dipartimento di Studi Umanistici, Università degli Studi di Ferrara (Italy)
}

Irene VALVERDE TEJEDOR

Grupo de Estudos para a Prehistoria do Noroeste Ibérico-Arqueoloxía, Antigüidade e Territorio (GEPN-AAT), Dpto. Historia, Universidade de Santiago de Compostela (Spain) and Sezione di Scienze Preistoriche e Antropologiche, Dipartimento di Studi Umanistici, Università degli Studi di Ferrara (Italy)

Augusto PÉREZ-ALBERTI Cross-Research in Environmental Technologies (CRETUS) Universidade de Santiago Compostela (Spain)

Pedro P. CUNHA University of Coimbra, Department of Earth Sciences, MARE - Marine and Environmental Sciences Centre (Portugal)

Hugo BAL GARCÍA

Grupo de Estudos para a Prehistoria do Noroeste Ibérico-Arqueoloxía, Antigüidade e Territorio (GEPN-AAT), Dpto. Historia, Universidade de Santiago de Compostela (Spain) 
Xes ALDEA MOREIRA

Grupo de Estudos para a Prehistoria do Noroeste Ibérico-Arqueoloxía,

Antigüidade e Territorio (GEPN-AAT), Dpto. Historia,

Universidade de Santiago de Compostela (Spain) and Institut Català de Paleoecologia Humana i Evolució Social (IPHES-CERCA), Tarragona (Spain) and Universitat Rovira i Virgili, Departament d'Història i Història de l'Art, Tarragona (Spain)

Cristian LORENZO SALGUEIRO Tania MOSQUERA CASTRO Ramón FÁBREGAS VALCARCE

Grupo de Estudos para a Prehistoria do Noroeste Ibérico-Arqueoloxía, Antigüidade e Territorio (GEPN-AAT), Dpto. Historia, Universidade de Santiago de Compostela (Spain)

Submitted on 5 March 2020 | Accepted on 5 July 2020 | Published on 8 November 2021

Lombera-Hermida A. de, Rodríguez-Álvarez X. P., Ameijenda Iglesias A., Díaz Rodríguez M., Rey-Rodríguez I., Valverde Tejedor I., Pérez Alberti A., Cunha P. P., Bal García H., Aldea Moreira X., Lorenzo Salgueiro C., Mosquera Castro T. \& Fábregas Valcarce R. 2021. - Between two worlds: Cova Eirós and the Middle-Upper Palaeolithic transition in NW lberia, in Rodríguez-Álvarez X. P., Otte M., Lombera-Hermida A. de \& Fábregas-Valcarce R. (eds), Palaeolithic of Northwest Iberia and beyond: multidisciplinary approaches to the analysis of Late Quaternary hunter-gatherer societies. Comptes Rendus Palevol 20 (42): 859-886. https://doi.org/10.5852/cr-palevol2021v20a42

KEY WORDS

Middle-Upper

Palaeolithic transition, Mousterian,

Aurignacian,

quartz industries,

zooarchaeology,

Northwestern Iberia.

MOTS CLÉS

Transition

Paléolithique moyen-

Paléolithique supérieur,

Moustérien,

Aurignacien,

industries en quartz,

zooarcheologie,

Nord-Ouest de la

péninsule Ibérique.

\section{ABSTRACT}

Iberia, a natural cul-de-sac peninsula, plays a major role in the study of the Neanderthals demise and its eventual relationship with the spread of Anatomically Modern Humans (AMH) in Europe. The site of Cova Eirós (Galicia, Spain), located in NW Iberia, contains Middle and Upper Palaeolithic levels, based on the cultural remains recovered at the site. No human remains directly associated with those levels were discovered yet. The available radiocarbon dates from the levels 2 (c. $35 \mathrm{ka} \mathrm{cal} \mathrm{BP}$, Early Upper Paleolithic) and 3 (c. $41 \mathrm{ka} \mathrm{cal} \mathrm{BP,} \mathrm{Late} \mathrm{Middle} \mathrm{Paleolithic),} \mathrm{point} \mathrm{to} \mathrm{a} \mathrm{late} \mathrm{survival} \mathrm{of}$ Neanderthal groups in North Iberia and to a relative quick arrival of the AMH, c. 35-36 ka cal BP, with respect to other territories of the Iberian Peninsula. The archaeological record shows clear differences between the Middle and the Upper Palaeolithic occupations, regarding raw-material acquisition, lithic technology and subsistence strategies. The location of Cova Eirós in the westernmost margin of the Cantabrian Rim and in the Atlantic Façade, makes this site a key place to understand the spread of the first $\mathrm{AMH}$ and the progressive demise of Neanderthal populations.

\section{RÉSUMÉ}

Entre deux mondes : Cova Eirós et la transition Paléolithique moyen-supérieur dans le Nord-Ouest de la péninsule Ibérique.

Iberia, une péninsule naturelle en cul-de-sac, joue un rôle majeur dans l'étude de la disparition des Néandertaliens et de sa relation avec le déploiement des humains anatomiquement modernes $(\mathrm{AMH})$ en Europe. Le site de Cova Eirós (Galice, Espagne), situé dans le Nord-Ouest de la péninsule Ibérique, comprend une séquence avec des niveaux du Paléolithique moyen et supérieur, d'après les vestiges culturels retrouvés sur le site. Aucun reste humain directement associé à ces niveaux n’a encore été découvert. Les datations au radiocarbone des niveaux 2 (c. $35 \mathrm{ka} \mathrm{cal} \mathrm{BP} \mathrm{Paléolithique}$ supérieur initial) et 3 (c. $41 \mathrm{ka}$ cal BP Paléolithique moyen final) indiquent une survie tardive des groupes néandertaliens en Ibérie du Nord et une arrivée relativement rapide d'AMH - vers 35-36 ka cal. BP - par rapport aux autres territoires de la péninsule Ibérique. Les données archéologiques montrent de fortes différences entre les occupations du Paléolithique moyen et supérieur en ce qui concerne l'acquisition de matières premières, la technologie lithique et les stratégies de subsistance. L’emplacement de Cova Eirós dans la marge la plus à l'ouest de la rive cantabrique et de la façade atlantique, fait de ce site un endroit clé pour comprendre le déploiement des premiers AMH et la disparition progressive des populations néandertaliennes. 


\section{INTRODUCTION}

The debate on the Middle to the Upper Palaeolithic transition in the Iberian Peninsula has a long tradition because of its implications for understanding the demise of Homo neanderthalensis in Europe, where several models (climatic, ecological, interspecific competitiveness, etc.) have been proposed (Straus 2005, 2012; Vaquero Rodríguez 2006; Finlayson \& Carrión 2007; Bernaldo de Quirós \& Maíllo-Fernández 2009). Among them, the Ebro Frontier stands out: according to Zilhão (2000, 2006), the Ebro River was a long-standing "biogeographic barrier", which implied a millennial coexistence between populations of $H$. sapiens and $H$. neanderthalensis in the NE sector of the Iberian Peninsula. This model has been discussed, partly due to some troublesome stratigraphic features of the key sites. In the last decade, new archeo-stratigraphic revisions of the reference sequences (Vaquero Rodríguez 2006; Vaquero et al. 2006; Martínez-Moreno et al. 2010; Mallol et al. 2012; Garralda et al. 2014) and, especially, the application of new pre-treatments for radiocarbon dating have made possible to calibrate and specify the chronological context of the Middle-Upper Palaeolithic transition. As a result, late Mousterian levels of Cantabrian sites with quite recent dates have been significantly revised and/or questioned due to problems related to their stratigraphic context (Jöris \& Street 2008; Maroto et al. 2012; Santamaría Álvarez \& de la Rasilla Vives 2013; Higham et al. 2014; Wood et al. 2014, 2016; Menendez et al. 2017; Gutiérrez-Zugasti et al. 2018 inter alia). In contrast, South Iberian sites show ages later than 30 ky BP (Finlayson et al. 2006; Zilhão et al. 2017), implying a survival of the Middle Palaeolithic groups quite a long time after the first arrival and settlement of Homo sapiens in the north. In Cantabria, only the Esquilleu sequence (Cantabria) seems to support late dates for the Mousterian groups (Baena et al. 2012; Baena-Preysler et al. 2019).

Placed at the end of the coastal Cantabrian Rim, NW Iberia is an important area for understanding the timing of the Neanderthal demise and the first dispersal of AMH out of the Franco-Cantabrian region (e.g. Haws et al. 2010; Cunha et al. 2019). From that western outpost, the Miño River and the adjacent Cenozoic basins are the natural corridors leading to the Atlantic shores (de Lombera-Hermida et al. 2015). Unfortunately, the Iberian NW is defined by the predominance of a Paleozoic substratum that, due to the acidity of its soils, prevents the conservation of organic materials in open-air sites. In addition, the undulating orography, that favors erosive and morphogenetic processes, severely thwarts the preservation of archaeological records. On the other hand, in NW Iberia the raw material availability is almost restricted to vein quartz and quartzite. Thus, the application of conventional Upper Palaeolithic typological schemes is very limited. These determining factors lead to lithic assemblages with formal and typological peculiarities that may hinder a precise chrono-cultural ascription.

In this paper we intend to shed light on the transition from the Middle to the Upper Palaeolithic in NW Iberia, based on the stratigraphic sequence of the Cova Eirós site.
We will focus specifically on the study of the archaeological records from Level 2 (Early Upper Palaeolithic) and Level 3 (Late Middle Palaeolithic).

\section{COVA EIRÓS SITE}

The Cova Eirós site is located in Cancelo (a village of the Triacastela municipality) (Lugo, Spain) (UTM X: 646.855; UTM Y: 4.736.428) (Fig. 1). The cave entrance is on the NNW slope of Monte Penedo in Serra do Ouribio, at $785 \mathrm{~m}$ a.s.l. and $25 \mathrm{~m}$ above a stream, the Arroyo de Bezcas. The Cova Eirós karstic system is part of the Cándana Limestone Series, formed during the Lower Cambrian. The cave is $312 \mathrm{~m}$ long and the entrance, where the Palaeolithic groups settled; currently is $2 \mathrm{~m}$ high by $3.5 \mathrm{~m}$ wide, narrowing after the first $7 \mathrm{~m}$ into a $15 \mathrm{~m}$ long neck (Rodríguez-Álvarez et al. 2011; de Lombera Hermida et al. 2014). Then, the cave continues inwards in a NNW direction in a series of three overlapping levels of galleries. The Palaeolithic engravings and paintings spread along the main Hall and Gallery (de LomberaHermida \& Fábregas-Valcarce 2013; Fábregas-Valcarce et al. 2015; Steelman et al. 2017).

\section{STRATIGRAPHIC CONTEXT}

The cave entrance of the Cova Eirós contains an excavated sedimentary succession up to $c .2 \mathrm{~m}$ thick. According to a GPR survey, the maximum thickness of the sedimentary succession that covers the limestone basement is $c .3 .4 \mathrm{~m}$.

From the surface of the sedimentary infill to the lower level of the present excavated sequence, several archaeological levels (layers) were defined (referred as A, B, 1, 2, 3, 4 and 5, from top to bottom), in which the respective depositional facies were identified (Fig. 2).

\section{Level 5}

Coarse silt with dispersed very angular pebbles of limestone. Currently under excavation.

Level 4

Three layers were identified:

Layer 4AI. Very fine sand to coarse silt with dispersed rounded pebbles of limestone and schist, but also very angular pebbles of limestone; thickness: $5 \mathrm{~cm}$. Contains a Mousterian industry with expedient, Levallois and discoidal products.

Layer 4C. Very coarse silt with widespread carbonate concretions and rounded pebbles of schist and limestone, but also very angular pebbles of limestone; thickness: $8-14 \mathrm{~cm}$. Contains a Mousterian industry with Levallois production.

Layer 4AS. Coarse silt with some dispersed rounded pebbles of white quartz, quartzite, schist and limestone (clasts usually of $3 \mathrm{~cm}$, sometimes reaching $12 \mathrm{~cm}$ ), but also very angular pebbles and cobbles of limestone; thickness: 7-12 cm. Contains a Mousterian industry with Levallois and discoidal production. 


\section{Level 3}

Three layers were identified:

Layer 3C. Coarse silt, with dispersed very angular small pebbles of limestone and some small carbonate micritic concretions and laminations; thickness: $<12 \mathrm{~cm}$. Contains a Mousterian industry with Levallois and discoidal production.

Layer 3B. Very fine sand with dispersed very angular pebbles and cobbles of limestone (usually $2 \mathrm{~cm}$, but reaching $10 \mathrm{~cm}$ ); thickness: $8-10 \mathrm{~cm}$. Contains a Mousterian industry with Levallois and discoidal production.

Layer 3A. Fine to very fine sand, with dispersed very angular pebbles and cobbles of limestone (usually $2 \mathrm{~cm}$, but reaching $10 \mathrm{~cm}$ ), more abundant at the base; thickness: $<25 \mathrm{~cm}$. Contains a Mousterian industry with Levallois, discoidal and Kombewa production.

\section{Level 2}

Two layers were identified:

Layer 2B. Fine sand, with dispersed very angular small pebbles of limestone (up to $10 \mathrm{~cm}$ ) and some small carbonate concretions; thickness: $<16 \mathrm{~cm}$. Contains an Aurignacian industry with bladelet production.

Layer 2A. Very fine sand to coarse silt, with dispersed very angular small pebbles to cobbles of limestone (up to $10 \mathrm{~cm}$ ) and some small carbonate concretions; thickness: $6-20 \mathrm{~cm}$. Contains an Aurignacian industry with bladelet production and expedient knapping methods.

\section{Level 1}

Two facies were identified:

Layer 1B. Very fine sand, with dispersed very angular, very small pebbles of limestone. Horizontal lamination; thickness: $5-10 \mathrm{~cm}$. Contains a Gravettian industry with bladelet production, backed elements and points.

Layer 1A. Aeolian sands, with horizontal lamination. The lower part of this layer displays alternations of medium to fine sands passing upwards to fine sands, showing curved laminations. A middle stratigraphic level contains angular limestone cobbles to boulders. The upper part of the layer comprises fine sand with dispersed very angular very small pebbles of limestone; thickness: $10-40 \mathrm{~cm}$. No artefacts were found.

\section{Level B}

Two layers were identified:

Layer Ba. Very fine aeolian sands, with dispersed very angular small pebbles of limestone. It contains organic microaggregates and buried superficial organic horizons, interpreted as a paleosol; thickness: $2-4 \mathrm{~cm}$. Contains a Late Magdalenian industry with bladelet production, small backed tools and points.
Layer B. It comprises aeolian fine sediments, namely very fine sand at the base passing upwards to very coarse silt; displays horizontal lamination; thickness: $30-50 \mathrm{~cm}$. No artefacts were found.

Layer A1 and A2. These uppermost layers are extensive and have a gentle slope towards the inside of the cave. They consist of very poorly sorted silts to very fine sands with dispersed very angular cobbles to boulders of limestone and some cobbles of quartzite (these anthropically transported). Medieval pottery and structures were found.

The lower and upper boundaries of each layer are irregular. The most significant sedimentary disconformities are those, respectively, at the lower boundaries of layers A1 and 2B. The studied succession shows evidences of several sedimentary processes: 1) very angular limestone clasts (pebbles to boulders) that fell from the ceiling and walls of the cave are mainly observed in layers 3A, 2B, 2A and B. Layer 1A, very rich in very angular boulders of limestone, probably recording a gelifraction maximum period, related to an extreme cold event; 2) silting by karstic laminar flow along the cave gallery (specially 1B, 1A, and Ba); 3) deposition of aeolian sands transported from the outside area of the cave entrance (layers 4, 3, 2, 1B, B and specially 1A); 4) depositional influence of periods of superficial cover by snow (horizontal alignment of gelifracts) is interpreted for layers $2 \mathrm{~B}$ and $\mathrm{B} ; 5$ ) accumulation of scree talus at the cave entrance (layers A2 and A1).

\section{CHRONOLOGICAL FRAMEWORK}

Several Radiocarbon and OSL dates are available for this stratigraphic sequence (Table 1). Currently, an ambitious program is being carried out in order to obtain a robust basis for the establishment of the chronological framework between the last occupations of Neanderthals and the first occurrence of $H$. sapiens at Cova Eirós. The combination of OSL and radiocarbon dates applying ultrafiltration protocols (Higham et al. 2011, 2014) seeks to establish a time frame as accurate as possible.

For Level 2, the OSL date provided a value of $32.8 \pm 2.5 \mathrm{kyrs}$ $\mathrm{BP}$ (MAD-5611BIN), consistent with the radiocarbon data (Beta - 254280) of 36.1-35.0 kyrs cal BP, giving a chronological range for the Level 2 occupations that correlate to the last part of Marine Isotope Stage (MIS) 3, placing them between GIS 7 and GIS 6.

However, dating of Level 3 is problematic due to the discrepancy observed between the first OSL dates and subsequent results of the palaeoenvironmental and sedimentological studies. Initially, for Level 3 two dates were obtained by OSL at the Universidad Autónoma de Madrid (UAM): $87540 \pm$ 6112 yrs BP (MAD-5951BIN) and $84807 \pm 4919$ yrs BP (MAD-5612BIN). Therefore, the Neanderthal occupations of Level 3 would be placed at the MIS 5b insterstadial, defined in the Iberian northwest by a temperate and humid climate, with abundant deciduous taxa (Ramil Rego et al. 2005; Roucoux et al. 2005; Fletcher et al. 2010; Ramil-Rego et al. 2010). However, the study of small mammals and herpetofauna showed that the palaeoenvironmental differences between 

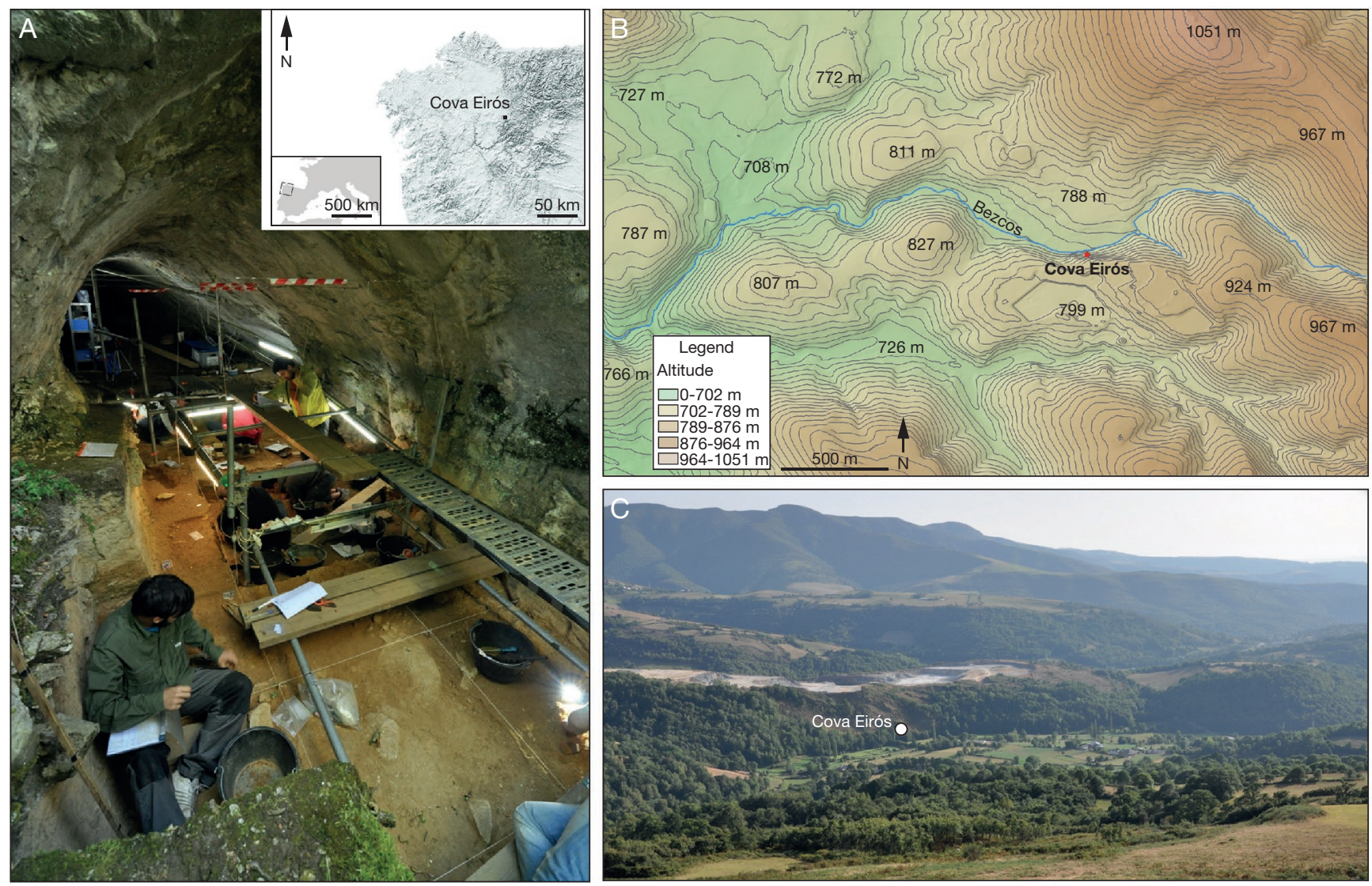

FIG. 1. - A, View of the current archaeological excavations at the entrance of Cova Eirós; B; location of Cova Eirós and the Cancelo Valley; C, view of the Cova Eirós cave in Monte Penedo and the Oribio Range in the background (1440 m a.s.l.).

TABLE 1. - Absolute dates obtained from the stratigraphic sequence located at the entrance of Cova Eirós (from bottom to top). Calibration was made using Oxcal 4.3 (Ramsey 2009) applying the calibration curves defined by Reimer et al. (2016).

\begin{tabular}{lllllll}
\hline Level & Ref. Lab. & Method & Sample & Years BP & Years cal BP/ cal AD & Reference \\
\hline Level 3 & MAD-5612BIN & OSL & Sediment & $84,807 \pm 4919$ & - & Rodríguez-Álvarez et al. 2011 \\
Level 3 & MAD-5951BIN & OSL & Sediment & $87540 \pm 6112$ & - & Inedit \\
Level 3 & OxA-30471 & C14-AMS & Bone & $35100 \pm 700$ & $41299-38390$ cal BP & Rey-Rodríguez et al. 2016 \\
Level 2 & Beta - 254280 & C14-AMS & Bone & $31690 \pm 240$ & $36136-35032$ cal BP & Rodríguez-Álvarez et al. 2011 \\
Level 2 & MAD-5611BIN & OSL & Sediment & $32787 \pm 2478$ & - & Inedit \\
Level 1 & MAD-5603BIN & OSL & Sediment & $17020 \pm 1321$ & - & Rey-Rodríguez et al. 2016 \\
Level B & Beta - 308859 & C14-AMS & Charcoal & $12040 \pm 50$ & $14045-13755$ cal BP & Fábregas Valcarce et al. 2012 \\
Surface Level (UA6) & Beta-308578 & C14-AMS & Charcoal & $1040 \pm 30$ & $901-1033$ cal AD & Fábregas Valcarce et al. 2012 \\
\hline
\end{tabular}

the levels of the Middle and Upper Palaeolithic of Cova Eirós were not as drastic as one might expect between a temperate interglacial period (MIS 5, Level 3) and a period marked by progressive cooling (MIS 3, Level 2) (Ramil-Rego et al. 2005, 2010; Rey-Rodríguez et al. 2016). Given this situation, new samples collected from the top part of Level 3 were sent to the Oxford Radiocarbon Accelerator Unit (ORAU). The new radiocarbon dating places the Level 3 occupations at around 41 kyrs cal BP (Table 1) offering a parsimonious interpretation with the archaeological and palaeoenvironmental data of Levels 2 and 3 (Rey-Rodríguez et al. 2016). This new radiocarbon age points to a very late survival of Neanderthal communities in NW Iberia compared to that stablished for the Cantabrian region (Higham et al. 2014; Marín-Arroyo et al. 2018). Incoming radiocarbon and OSL dates will help us to better define the chronology of the Level 3 of Cova Eirós.

\section{MATERIAL AND METHODS}

In this paper we study the archeo-paleontological materials from levels 2 and 3 of Cova Eirós, recovered during the 20082014 fieldwork seasons. The analysis of Level 2 is complete, but the excavations of Level 3 continued into 2018.

Osteological remains coming from the archaeological levels 2 and 3 of Cova Eirós have been studied from a taphonomical 
and zooarchaeological perspective. NISP, MNE, MNI, $\% \mathrm{MAU}$ were calculated and age profiles estimated based on eruption and wear stages of teeth, bone tissue and epiphysis fusion (Klein et al. 1981; Hillson 2016). Macroscopical and microscopical analyses were carried out on all the bones, teeth and antler surfaces. Cutmarks (Binford 1981; Shipman \& Rose 1983; Shipman et al. 1984; Fernandez-Jalvo \& Andrews 2016) and bone breakage patterns (Blumenschine \& Selvaggio 1988; Fernández-Jalvo et al. 1996; Díez et al. 1999; Rosell Ardèvol 2001) were studied. Carnivore damage such as chewing, furrows, scores and digestion were analysed. Epiphysis/diaphysis ratio and (vertebrae+ribs)/(limb bones) ratio were calculated to evaluate carnivore activity and hominid/ carnivore competition (Domínguez-Rodrigo \& Piqueras 2003). Post-depositional evidence consists of trampling, burn, manganese and weathering.

Moreover, in this paper we study the small-vertebrate remains from the excavation campaigns carried out between 2009 and 2014. The sample of small vertebrates from levels 2 and 3 has a number of identified specimens (NISP) of 208, which corresponds to a minimum number of individuals (MNI) of 129, representing at least 18 taxa (Rey-Rodríguez et al. 2016).

The small mammals assemblage was identified following the palaeontological criteria established by Furió (2007) for insectivores, Sevilla (1988) for Chiroptera, (López-García 2011; López-García et al. 2011) for rodents and Blain (2009) for anurans and snakes. The palaeoenvironmental reconstruction made use of the Habitat Weighting method (Evans et al. 1981; Andrews 2006; Blain et al. 2008; López-García et al. 2011). In order to reconstruct the palaeoclimatic conditions in Cova Eirós we apply the Mutual Ecogeographic Range (MER) method (Blain et al. 2009, 2016) and also the Bioclimatic Model (BM) (Hernández Fernández 2001) (see details about these in Rey-Rodriguez et al. 2016). By means of the MER and $\mathrm{BM}$ we are able to estimate the mean annual temperature (MAT), the mean temperature of the coldest month (MTC), the mean temperature of the warmest month (MTW) and the mean annual precipitation (MAP).

The study of the lithic industry has been carried out under a processual chaîne opératoire approach (Pelegrin et al. 1988), based on the attributes established by the Logical Analytical System (LAS, Carbonell et al. 1983, 1992) for the analysis of the exploitation and shaping processes. Typological aspects were recorded according to the analytical typology of G. Laplace (Laplace \& Saenz de Buruaga 2000). In levels 2 and 3 of Cova Eirós, the use of quartz and quartzite stands out. For the study of quartz, we distinguish between xenomorphic (anhedral) and automorphic (euhedral) quartz. Quartz artefacts were therefore placed into four morpho-structural groups on the basis of the presence/absence of grainy texture and of internal flaws or cleavage planes: NN (no grain, no plane), NY (no grain, plane), YN (grainy, no plane) and YY (grainy, plane). In this way, we identify two main types of xenomorphic quartz according to the macroscopic texture they display: granular textured quartz (YY and $\mathrm{YN}$ groups) and macrocrystalline quartz (NY and $\mathrm{NN}$ groups). This classification on the basis of quartz formation and mechanical properties makes it possible to recognize the technological or economic criteria applied to the selection of artefacts in accordance with the prevalent technical needs of prehistoric communities (Martínez Cortizas \& Llana Rodríguez 1996; de Lombera Hermida 2009). The morphotechnic analysis of the artefacts allows us to infer the exploitation and shaping strategies that define each lithic assemblage.

\section{RESULTS}

\section{The Level 3 of Cova EIrós \\ Lithic assemblage}

The analyzed lithic assemblage is composed of 520 artefacts, mostly belonging to the layer $3 \mathrm{~A}$, although the inventory of this layer amounts to more than 1900 lithics. Xenomorphic quartz was the most commonly used raw material in Level 3 (89.4\%), followed by quartzite $(9.0 \%)$, automorphic quartz $(1.4 \%)$ and limestone (with a single element) (Table 2). Fundamentally, there is a use of raw materials from the local environment $(0-5 \mathrm{~km})$, mainly from secondary deposits in the nearby riverbeds: the coarse and medium grained quartzites belong to the Upper Cándana formations (Lower Cambrian). Only the fine-grained varieties of quartzite, defined by their high metamorphism, are allochthonous (Armorican Quartzite, 10-20 km away). The overrepresentation of good quality products in quartz (mostly morphoestructural group $\mathrm{NN}$ ) and fine-grained quartzite over natural occurrences in the secondary deposits highlights the application of selective criteria during lithic supply. In the lithic assemblage knapping products $(87.7 \%)$ are predominant over the elements related to percussion $(2.5 \%)$, shaping $(6.4 \%)$ and production $(2.9 \%)$. The presence of natural Bases (manuports and percussive elements) is scarce $(\mathrm{n}=13 ; 2.5 \%)$. Only five of them show clear percussion marks and given the small size of the percussive material, with an average length between $67 \mathrm{~mm}$ and $86 \mathrm{~mm}$ long, they could be related to retouching and tool kit maintenance.

There is a differential management of the raw materials according to their local or allochthonous provenance and quality. The different stages of the chaîne opératoire are complete only in those raw materials of local origin, i.e., the NY xenomorphic quartz and the medium and coarsegrained varieties of quartzite. The cores recovered in this level $(n=13)$ are on those materials, the artefacts show a higher presence of cortical surfaces and there is a larger representation of knapping debris. On the other hand, the reduction sequences among fine-grained quartzites and $\mathrm{NN}$ xenomorphic quartz are fragmented, being only represented by medium-sized knapping products (flakes) and/or scarce elements related to retouching processes.

Despite the small number of cores, a wide variety of knapping methods is reported at Level 3 either by the presence of cores or the final products. They are defined by a mixture of expedient reduction methods (bipolar-on-anvil reduction, longitudinal, orthogonal and centripetal) and structured and hierarchical methods implying a higher volumetric and 


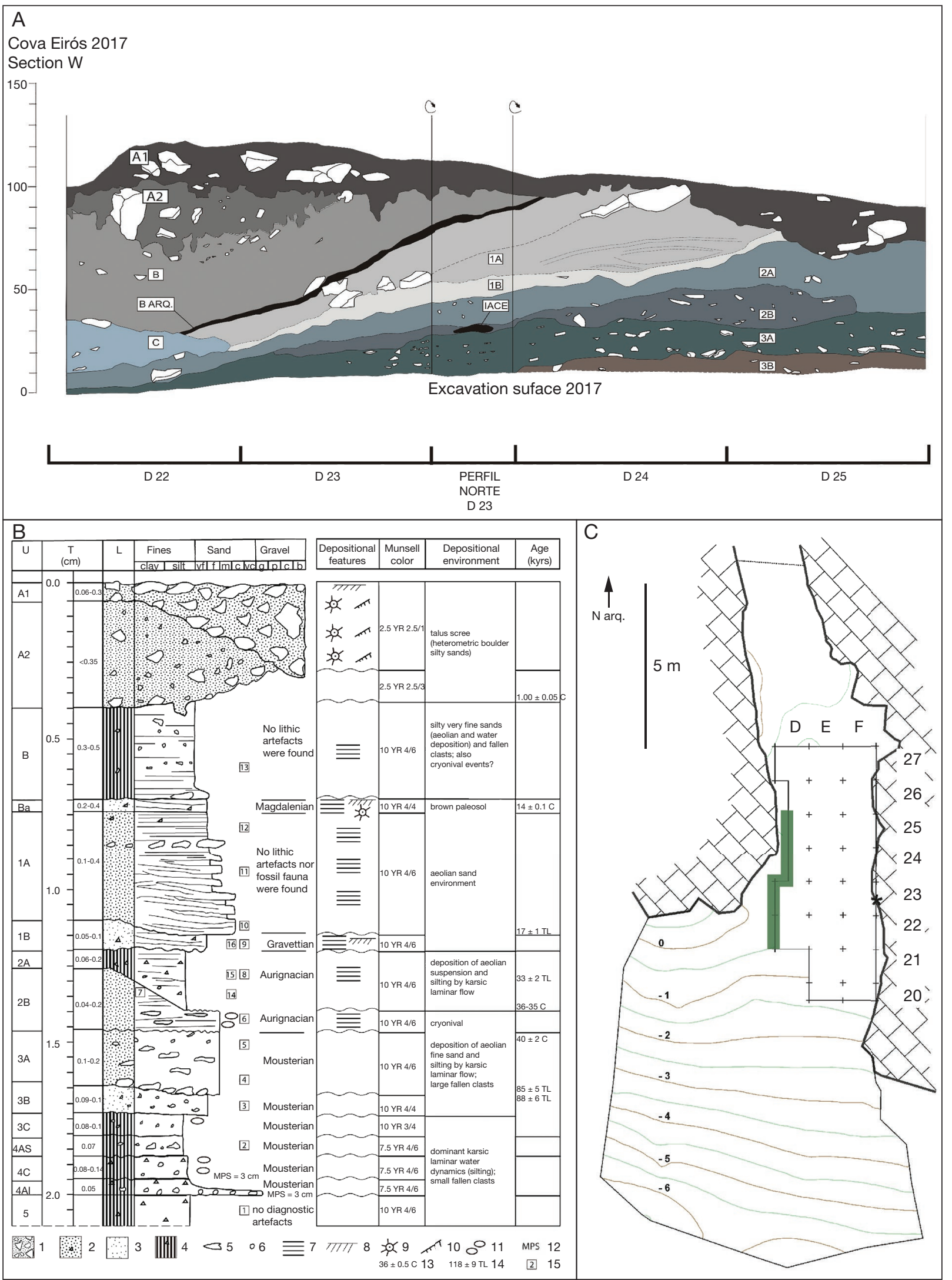

FIG. 2. - A, Stratigraphic section of Cova Eirós (west section); B, stratigraphic column of the excavated sedimentary infill, at the entrance of the Cova Eirós cave. Abbreviations: U, levels and layers; T, thickness; L, lithology; 1, gravel; 2, pebbly sand; $\mathbf{3}$, sand; $\mathbf{4}$, silt; $\mathbf{5}$, angular clast of limestone; $\mathbf{6}$, round clast of quartzite/ quartz; 7, depositional lamination; 8, paleosoil; 9, muddy microaggregate; 10, organic microaggregate; 11, carbonate concretion; 12, maximum pebble size; 13, C14 age; 14, Thermo-luminescence (TL) age; 15, new sediment sample for sedimentological characterization and Optically Stimulated Luminescence (OSL) dating. The types of lithic industries associated with each archaeological level are indicated. C, grid of the archaeological excavation at the entrance of the Cave. 
TABLE 2. - Lithic assemblage of the Level 3 of Cova Eirós according to their lithic category and raw material classification. Bold: totals and subtotals.

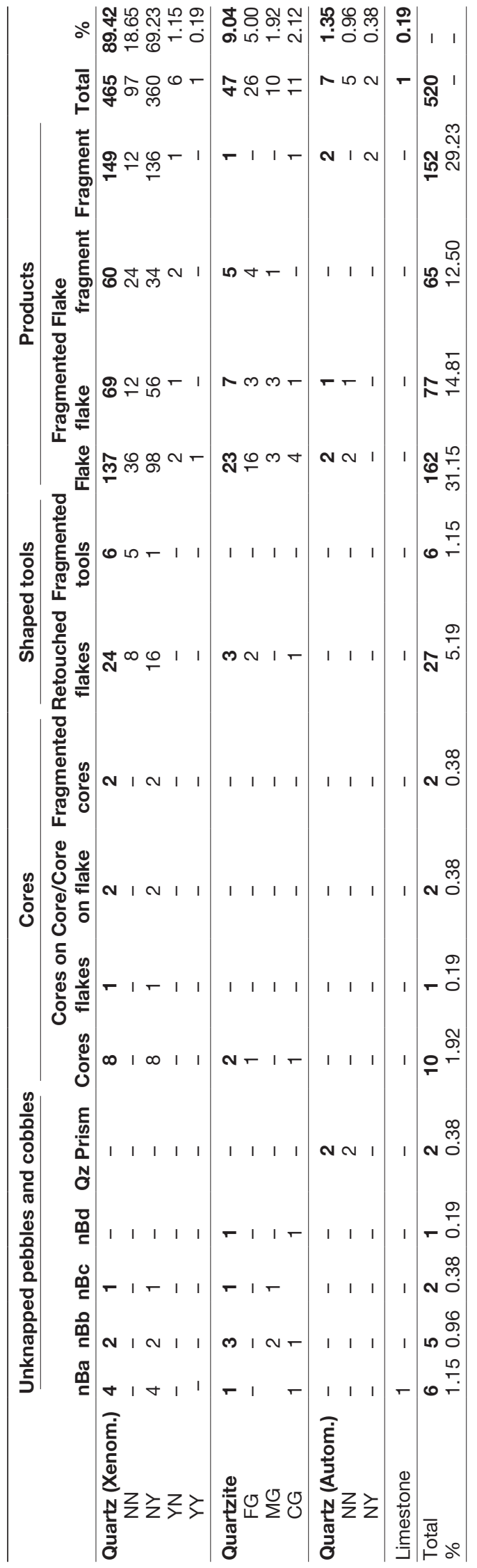

morphological predetermination (hierarchical centripetal/ Levallois, discoidal and Kombewa). The objective is obtaining flakes of different sizes and with predetermined and standardized morphologies and morphopotencials. Meanwhile, expedient strategies are mainly applied on local quartz and quartzite. Pebbles are initially knapped following longitudinal strategies that later yield orthogonal and centripetal morphologies, denoting a continuum between the reduction sequences based on the maximum perimeter, faciality and volumetric profit of cores and taking advantage of the cortical surfaces and scars as striking surfaces (i.e., de LomberaHermida et al. 2011). Most of the production is focused on obtaining small flakes in xenomorphic quartz, through an exploitation based on the bifacial centripetal reduction of the cores that, in advanced stages, give rise to orthogonal trifacial and multifacial strategies. These methods fall within the variability of the centripetal schemes (Mourre 2003) but without fully showing the volumetric structuring of the discoidal method. The bipolar-on-anvil reduction $(n=3)$ is applied exclusively on quartz as a complementary method aimed at the obtaining of small sized flakes (Fig. 3).

The application of structured and complex reduction strategies is attested by the discoidal, centripetal hierarchized (Levallois) and Kombewa products. The discoidal method is represented mainly by cordal and debordant flakes clearly linked to this method of exploitation in xenomorphic quartz (groups NN and NY) and, to a lesser extent, the so-called pseudo-Levallois points in fine-grained quartzite. Only a NY quartz core and a fragmented core in quartzite were recovered. Besides, two NY quartz cores show clear hierarchization of the flaking surfaces, focused in the preferential exploitation of those without internal flaws. Nevertheless, there is no configuration of the latero-transversal surfaces (i.e., Hopkinson et al. 2013). The application of the Levallois method sensu stricto at Level 3 of Cova Eirós is attested by the predetermined products (preferential flakes and points) made on fine-grained quartzite or high-quality xenomorphic quartz (NN group). The use of the recurrent centripetal and point Levallois methods can be inferred thanks to the characteristics of these products (Boëda 1994). The absence of cores on these raw material varieties and the scarce number of predetermining elements related to this method are indications of the spatial fragmentation of their operative chains. These Levallois products could be considered as mobile and curated tools but, on the contrary, no maintenance or shaping retouch usually aimed at increasing the tool's life is observed (Dibble 1987; Kuhn 1992; Turq et al. 2013). The Kombewa method is only documented by final products. As stated before, despite the scarcity of cores in the assemblage a wide variety of exploitation methods is reported. The fragmented nature of their knapping sequences (mostly represented by final and diagnostic products) and the scarcity of predetermining products suggest that the lithic reduction was performed outside the cave as a result of different knapping sequences, and not as a continuum during the reduction processes (especially those on fine-grained quartzite).

The knapping products are the predominant elements in the lithic assemblage of Level $3(87.7 \%)$. The percentages of 


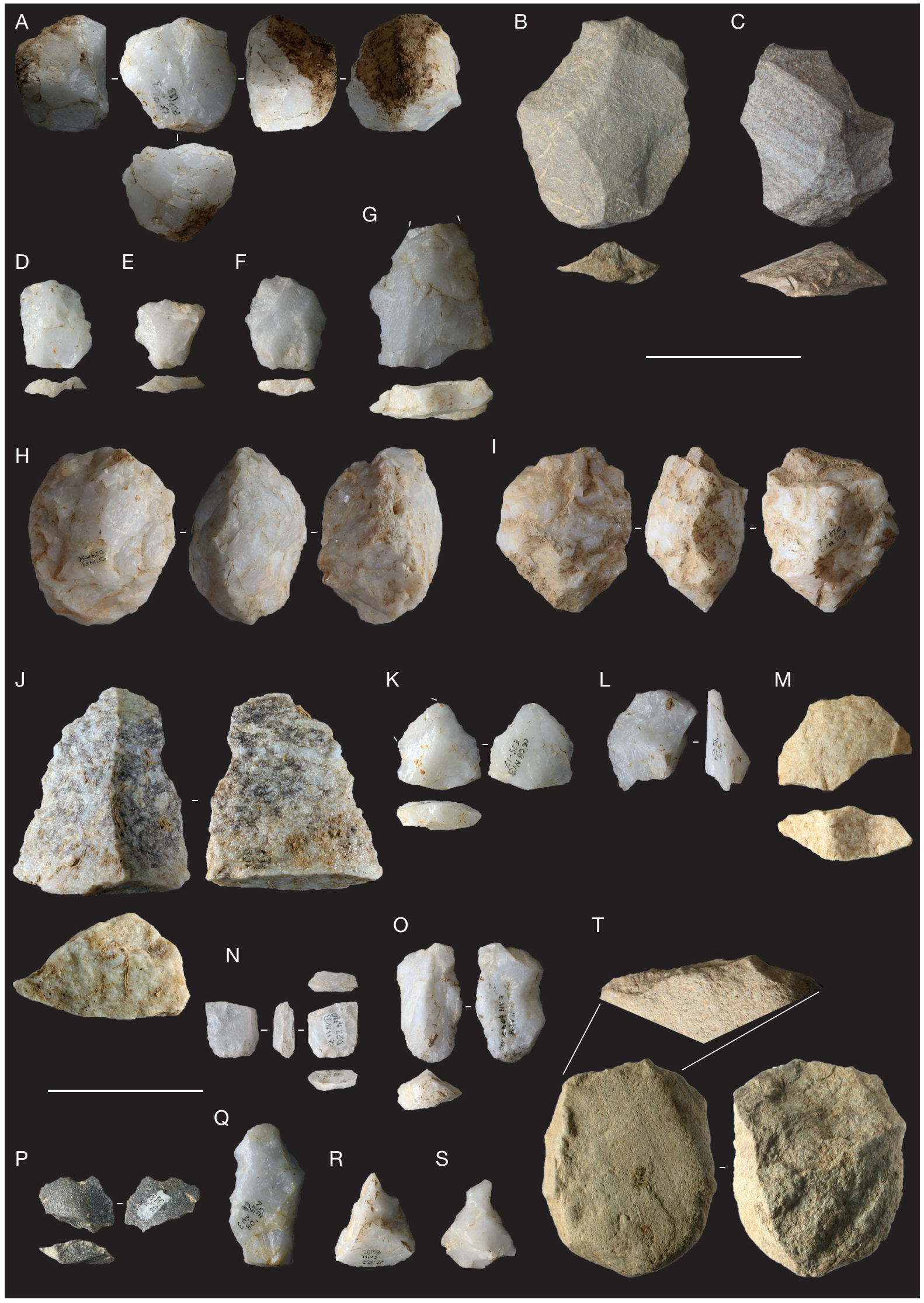

FIG. 3. - Lithic industry from Level 3: A, centripetal hierarchized core on quartz; B, C, preferential Levallois flakes on quartzite; D-G, Levallois flakes on quartz; $\mathbf{H}$, I, bifacial centripetal and discoidal cores on quartz; J, quartzite flake; K-M, discoidal flakes on quartz and quartzite (M); N, $\mathbf{O}$, bipolar core and product; $\mathbf{P}$, kombewa flake on quartzite; $\mathbf{Q}$, denticulated tool on quartz; $\mathbf{R}, \mathbf{S}$, becs on quartz, $\mathbf{T}$, cleaver on quartzite. Scale bars: $5 \mathrm{~cm}$. 
TABLE 3. - Number of identified specimens (NISP), percentage of the number of identified specimens (\%NISP), minimum number of elements (MNE), expected minimum number of elements (eMNE), and minimum number of individuals (MNI) of the main taxonomic groups identified at Level 3 from Cova Eirós.

\begin{tabular}{lrrrrr}
\hline Taxa & NISP & \%NISP & MNE eMNE MNI \\
\hline $\begin{array}{l}\text { Ursus spelaeus (Rosenmüller- } \\
\quad \text { Heinroth, 1794) }\end{array}$ & 84 & 48.2 & 77 & 2076 & 12 \\
Crocuta crocuta (Erxleben, 1777) & 5 & 2.9 & 1 & - & 1 \\
Panthera leo (Goldfuss, 1810) & 1 & 0.6 & 1 & 12 & 1 \\
Canis lupus (Linnaeus, 1758) & 2 & 1.1 & 1 & 26 & 1 \\
Vulpes vulpes (Linnaeus, 1758) & 2 & 1.1 & 2 & 74 & 1 \\
Sus scrofa (Linnaeus, 1758) & 1 & 0.6 & 1 & 48 & 1 \\
Coelodonta (Bronn, 1831) & 2 & 1.1 & 2 & - & 1 \\
Cervus elaphus (Linnaeus, 1758) & 20 & 10.9 & 20 & 116 & 5 \\
Capreolus capreolus (Linnaeus, & 6 & 4 & 6 & 168 & 3 \\
$\quad$ 1758) & & & & & \\
Bison priscus (Bojanus, 1827) & 12 & 6.9 & 9 & 63 & 3 \\
Capra pyrenaica (Schinz, 1838) & 1 & 0.6 & 1 & - & 1 \\
Rupicapra rupicapra (Linnaeus, & 22 & 12.6 & 20 & 248 & 4 \\
$\quad$ 1758) & & & & & \\
Oryctolagus cuniculus (Linnaeus, & 2 & 1.1 & 2 & - & 2 \\
$\quad$ 1758) & & & & & \\
\hline Total & 160 & 100 & 143 & 2,831 & 36 \\
\hline
\end{tabular}

fractured products (broken flakes and fragments of flakes) and knapping debris are high (14.8\%, 12.5\% and 29.3\%, respectively), due to the majoritarian use of xenomorphic quartz. The typometric analysis of the complete flakes indicates that the products obtained through these strategies are small sized -usually under $30 \mathrm{~mm}$ in length (average $20.3 \times 19.3 \times$ $7.9 \mathrm{~mm}$ )-, though some larger quartzite and Levallois flakes are reported as well $(46.2 \times 39.2 \times 11.5 \mathrm{~mm})$. The percentages of bifaceted (24.2\%) and multifaceted (14.3\%) butts among flakes are significant, mainly related to the discoidal and Levallois products.

The shaping strategies are focused exclusively on the retouching of non-cortical flakes (6.3\% of the total) of larger dimensions, both in quartz and quartzite $(31.4,26.2 \times 10.7 \mathrm{~mm}$ and $57.2 \times 57.6 \times 18.3 \mathrm{~mm}$, respectively). A significant aspect of this lithic assemblage is the nearly absence of retouching of fine-grained quartzites, which may indicate their use for specific and short activities, without major interest in extending the life of these artifacts. From the typological point of view, Level 3 is very conditioned by the predominance of xenomorphic quartz and the low entity of the retouching sequences. The denticulate group is majoritarian $(66.7 \%)$, especially with regard to notches $(33.3 \%)$ and denticulated side scrapers $(22.2 \%)$. Interestingly, one cleaver on quartzite was recovered.

Summing up, the lithic collection of Level 3 of Cova Eirós displays a series of particular characteristics with respect to other Iberian Middle Palaeolithic sites, conditioned by the predominance of xenomorphic quartz as raw material. It is defined by the differential management strategy of the assorted variety of raw materials according to their quality and mechanical characteristics based on the selection criteria in supply areas, the spatial fragmentation of chaînes opératoires and the application of knapping strategies aimed at the maximization of the raw material. These strategies are similar to those identified in other regions with similar lithological constraints (Jaubert 1997; Faivre et al. 2013). The use of longitudinal and discoidal methods can be considered as an adaptive response of Neanderthal groups to mediocre raw materials (Delagnes \& Rendu 2011; de Lombera Hermida et al. 2011; Daffara et al. 2018). Nevertheless, at Cova Eirós the Levallois production in good quality xenomorphic quartz shows that the raw material is not an unsurmountable constraint and reflects the knapper's deep knowledge of the mechanical characteristics of the stone varieties and its adaptation to the technical requirements of the operative chains. Although occasionally, its application in Levels 3 and 4 of Cova Eirós (Fábregas-Valcarce et al. 2012) and in other Middle Palaeolithic sites (Mourre 1996; Duran \& Soler 2006; Aubry et al. 2016) shows that raw material constraints can be overcome by blank selection and expertise (Eren et al. 2014).

\section{Zooarchaeology}

The faunal assemblage of Level 3 amounts to more than 3100 effectives, from which a sample of 703 elements are considered in this study. The taxonomic identification index is almost 25\% $(\mathrm{NISP}=174)$ with a minimum number of 13 species. Of the total NISP, about $90 \%$ are bones (NISP $=627$ ), $11 \%$ are teeth $(\mathrm{NISP}=75)$ and $0.1 \%$ correspond to antler remains (NISP $=$ 1). Among the remains without anatomical identification, 360 fragments (51\%) have been classified by weight sizes (Table 3).

The MNE of Level 3 is 253, underlining the widespread prevalence of the cranial skeleton (44\%), followed by axial skeleton (13\%), phalanges (9\%), metapods (7\%) and inferior appendicular skeleton (7\%). The distribution of MNE by taxa shows a clear predominance of cave bear $(n=77)$, followed by chamois $(n=20)$, deer $(n=17)$, bison $(n=9)$ and roe $\operatorname{deer}(\mathrm{n}=7)$. The MNI of Level 3 is 50 . The predominant species is Ursus spelaeus Rosenmüller-Heinroth, 1794, with a total of 12 individuals ( $24 \%$ of the total identified). The rest of the taxa have an MNI of less than 10: Cervus elaphus Linnaeus, 1758 has an NMI $=5(10 \%)$, Rupicapra rupicapra Linnaeus, 1758 has 4 individuals (8\%) and Capreolus capreolus Linnaeus, 17583 (6\%). Among carnivores, no species has more than one individual.

The age of death could be calculated for $80 \%$ of the total MNI ( $\mathrm{n}=40)$, which represents a very high percentage of identification for a Pleistocene faunal complex. We have observed a predominance of adult individuals (53\%) over sub-adults (25\%, with a total of ten individuals), neonates (20\%) and just one senile specimen.

Faunal remains showing cut marks amount to a $6 \%$ of the total record $(\mathrm{n}=40)$. Intentional anthropic fragmentation is evidenced by small flakes from cortical section (64\%), followed by fracture cones (18\%), hackle marks (10\%), peeling (7\%), adhering flakes (3\%) and finally, medullary flakes (1\%) and rebound (1\%).

A fragment of a Cervus elaphus antler tip with very interesting anthropic modifications has been identified: the proximal part has two percussion negatives resulting from the removal of flakes (Fig. 4). They are set parallel with respect to the sagittal axis, have a smooth surface and fresh fracture edges. 

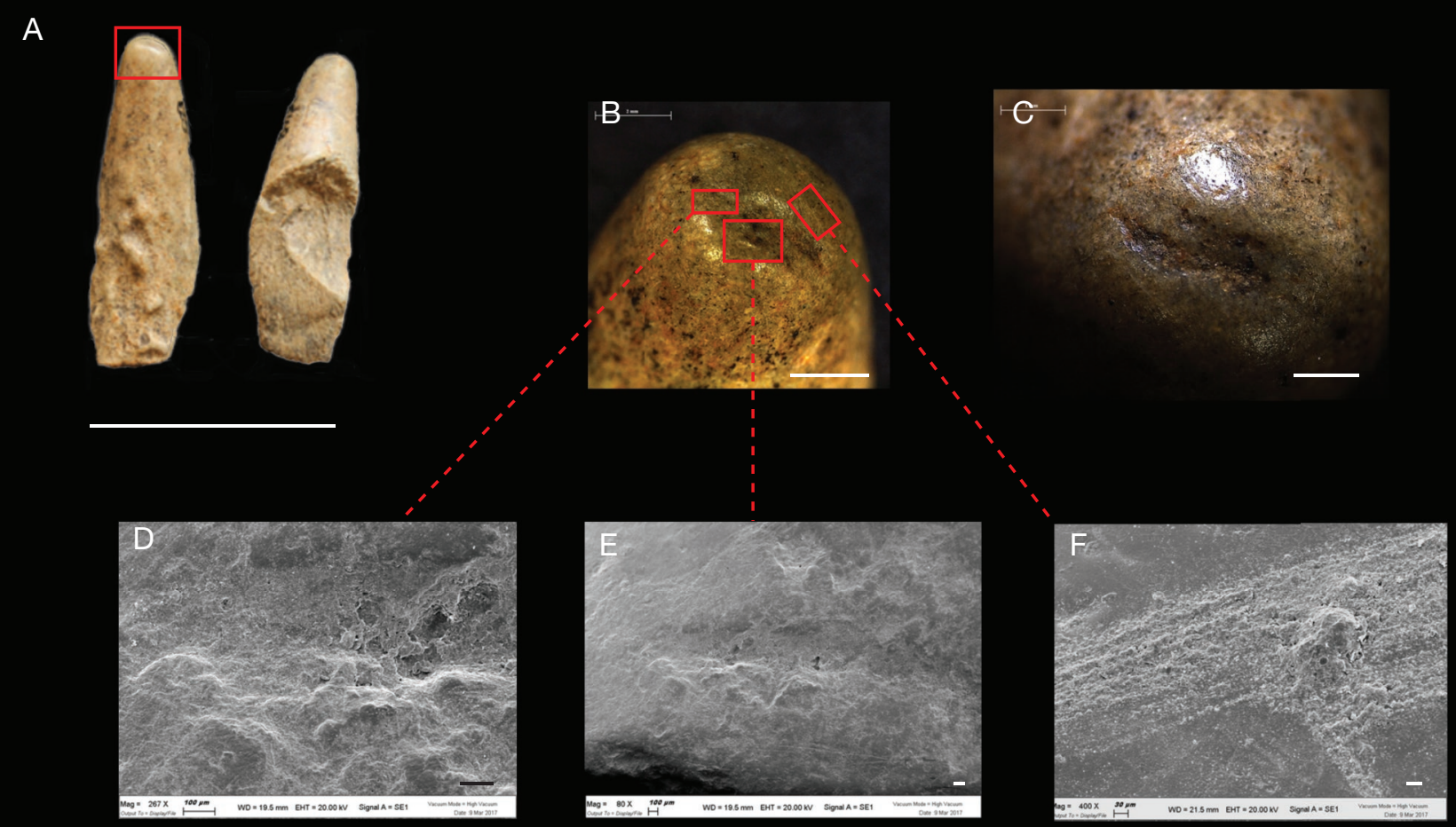

G
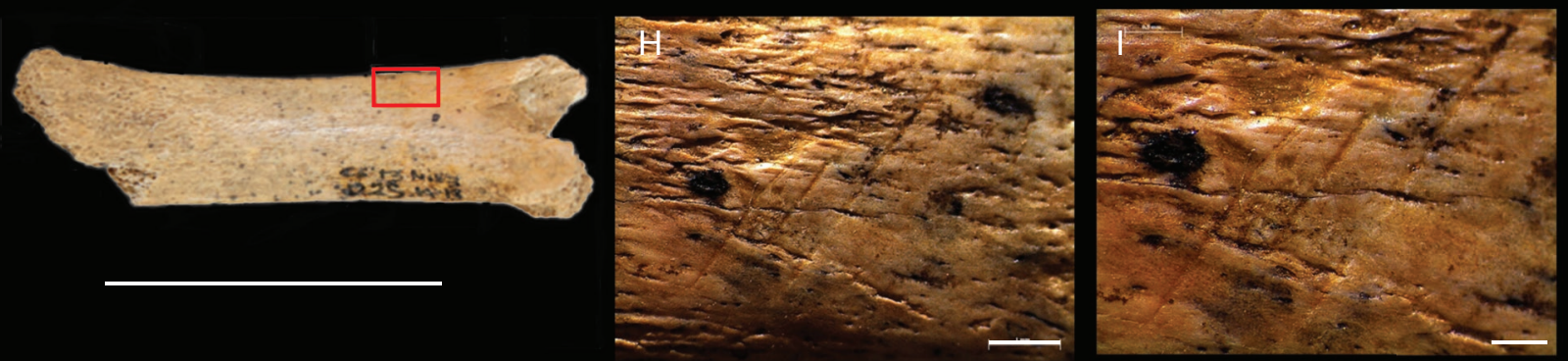

$\mathrm{J}$
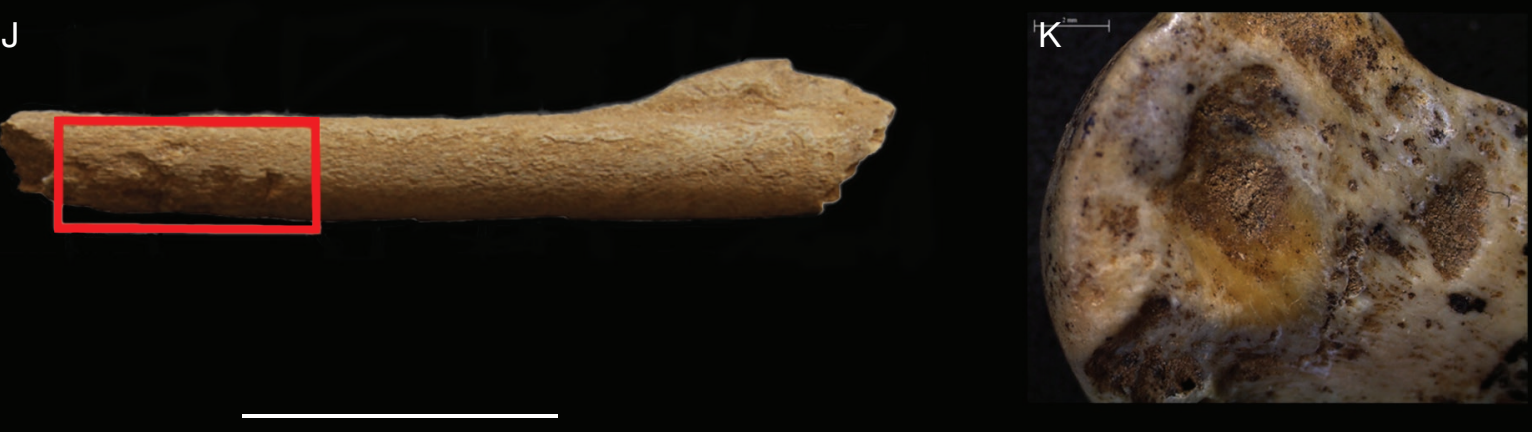

FIG. 4. - A-C, Cervus elaphus (Linnaeus, 1758) antler tip showing antropic breakage marks and details of the incisions under binocular stereo microscope (B, C); D-F, striae of the tip under ESEM; G, Panthera leo spelaea (Goldfuss, 1810) rib showing cutmarks; H, I, detail of the cutmarks under binocular stereo microscope; J, furrows on a diaphysis of a metapod belonging to a medium sized animal; K, digestion marks made by carnivores. Scale bars: A, B, F, I, $3 \mathrm{~cm}$; C, 300 $\mu$ m; $\mathrm{D}, \mathrm{H}, 20 \mu \mathrm{m} ; \mathrm{E}, 100 \mu \mathrm{m} ; \mathrm{G}, 0,5 \mathrm{~mm}$; J, $2 \mathrm{~mm}$. 
TABLE 4. - Number of identified specimens (NISP), minimum number of individuals (MNI) and percentage of the $\mathrm{MNI}(\%)$ for the small vertebrates from level 3 of Cova Eirós. Bold: totals and subtotals.

\begin{tabular}{lrrr}
\hline Taxa & NISP & MNI & \multicolumn{1}{c}{$\%$} \\
\hline Rana temporaria (Linnaeus, 1758) & 2 & 2 & 3.64 \\
Rodentia indet. & 2 & 0 & 0.00 \\
Apodemus sylvaticus (Linnaeus, 1758) & 3 & 2 & 3.64 \\
Arvicola amphibius (Linnaeus, 1758) & 5 & 3 & 5.45 \\
Arvicola sapidus (Miller, 1908) & 4 & 3 & 5.45 \\
Chionomys nivalis (Martins, 1842) & 3 & 2 & 3.64 \\
Microtus (Terricola) lusitanicus (Gerbe, 1879) & 12 & 8 & 14.55 \\
Microtus agrestis (Linnaeus, 1761) & 15 & 8 & 14.55 \\
Microtus arvalis (Pallas, 1779) & 16 & 8 & 14.55 \\
Microtus arvalis-agrestis (Pallas, 1779/ & 2 & 2 & 3.64 \\
$\quad$ Linnaeus,1761) & & & \\
Microtus oeconomus (Pallas, 1776) & 1 & 1 & 1.82 \\
Myotis myotis/blythii (Borkhausen, 1797/ & 3 & 2 & 3.64 \\
$\quad$ Tomes, 1857) & & & \\
Myotis sp. & 1 & 1 & 1.82 \\
Chiroptera indet. & 3 & 3 & 5.45 \\
Rhinolophus ferrumequinum (Schreber, 1774) & 1 & 1 & 1.82 \\
Sorex minutus (Linnaeus, 1766) & 3 & 2 & 3.64 \\
Sorex sp. & 7 & 5 & 9.09 \\
Talpa cf. occidentalis (Cabrera, 1907) & 2 & 2 & 3.64 \\
\hline Total & 85 & 55 & 100.00 \\
\hline
\end{tabular}

TABLE 5. - Values of temperature and precipitation for Cova Eirós Level 3 obtained by the Mutual Climatic Range method and the Bioclimatic Model. Abbreviations: MAP, mean annual precipitation; MAT, mean annual temperature; Max, maximum of values obtained; Min, minimum of values obtained; MTC, mean temperature of coldest month; MTW, mean temperature of warmest month; SD, standard deviation of values obtained; $\Delta$, difference between the values obtained by analysing the small mammals from Cova Eirós and current values.

\begin{tabular}{ccc}
\hline & Mutual Ecogeographic Range & Bioclimatic model \\
\hline MAT & 8.18 & 9.16 \\
SD & 1.17 & 3.39 \\
Max & 10 & - \\
Min & 7 & - \\
$\Delta$ & -2.92 & -1.94 \\
MTW & 15.82 & 18.37 \\
SD & 0.98 & 4.77 \\
Max & 18 & - \\
Min & 15 & - \\
$\Delta$ & -1.28 & 1.27 \\
MTC & 1.36 & 0.66 \\
SD & 1.36 & 4.66 \\
Max & 4 & - \\
Min & 0 & - \\
$\Delta$ & -4.54 & -5.24 \\
MAP & 1827 & 1322 \\
SD & 480 & 533 \\
Max & 2500 & - \\
Min & 800 & - \\
$\Delta$ & 794 & 289 \\
\hline
\end{tabular}

Two transversal incisions and straight/sinuous delineation have also been found at the top of the antler tip. The bottom line is rounded, broad and irregular, so we discard that are cut marks. The tip has marginal micro-striations and the surface is quite irregular. The morphology of the tip, the location of the marks and their characteristics seem to indicate that it is a discard produced during the preparation and realization of a projectile point (Tejero et al. 2016).
In Level 3, carnivores represent 36\% of the MNE. They are accumulating and modifying agents of the faunal assemblage and their activity is documented in $9 \%$ of the total remains $(\mathrm{NR}=60)$. The evidences attributed to the corrosive action of salivary enzymes (29\%), digested remains (16\%), furrows (15\%), pits (13\%) and scores (11\%) stand out. Punctures and generalized gnawing accounts for almost $7 \%$ of total marks (Fig. 4).

Faunal studies indicate an important specific biodiversity, related to interspersed forest environments and open humid areas, rocky areas and steep slopes. The frequency in the distribution of Ursus spelaeus remains stands out, although this is logical given that caves are the natural habitat of this species. The skeletal representation by species and weight size shows significant differences between the distribution of ungulates and carnivores: ungulates have a pattern characterized by the predominance of heads and legs, while among the carnivores the presence of axial and cranial skeleton elements stands out. The analysis of the cut marks shows a recurrent consumption of ungulates of small, large and very large size and of medium and small size carnivores, the latter indicating that the use by hominids of meat coming from carnivores is not occasional.

The scarcity of skeletal remains of scavenged carnivores, the relative abundance of low survival elements, the high level of fragmentation and low relative frequency of epiphysis indicate a very intensive use of faunal resources by hominins. These hominins occupied the cave intensively but with periods of temporary abandonment, in which the intrusions of carnivores in the cave would be frequent to scavenge the broken carcasses.

\section{Small mammals and palaeoenvironmental reconstruction}

The species that are represented in the Level 3 are: Arvicola sapidus (Miller,1908), Microtus oeconomus (Pallas, 1776), Myotis myotis/blythii (Borkhausen, 1797/Tomes, 1857), Myotis sp. and Sorex minutus (Linnaeus, 1766), but the most abundant are the common vole (Microtus arvalis; 15\%), the Lusitanian pine vole (Microtus (Terricola) lusitanicus; 15\%), the field vole (Microtus agrestis; 15\%) and the northern water vole (Arvicola amphibius; 6\%) (Table 4).

Regarding the palaeoclimatic conditions, Mutual Ecogeographic Range (MER) (Blain et al. 2016) and the Bioclimatic Model (BM) results suggested that the precipitation was higher and the temperatures lower than nowadays (Table 5). This Mousterian level has a habitat dominated by woodland (46\%), associated with species such as Apodemus sylvaticus (Linnaeus, 1758) and Myotis myotis/blythii. The proportion of open humid habitat $(26 \%)$ is also noticeable, due to the presence of taxa such as Rana temporaria (Linnaeus, 1758), Microtus (Terricola) lusitanicus (Gerbe, 1879) and Arvicola amphibius (Linnaeus, 1758). Arvicola sapidus is only present in this level, which is important because this taxon is always associated with stable water sources near the cave. This explains the percentage of aquatic environments (11\%) found in Level 3.

Also, relevant is the presence of the taxon Chionomys nivalis (Martins, 1842), with Central European requirements (3.6\%), and Microtus oeconomus (1.8\%). The snow vole (Chionomys nivalis) is associated with high mountains, and the presence 
of this taxon in the Iberian Peninsula is restricted to rocky areas (Palombo \& Sardella 2007). Microtus oeconomus, lives in open, cool environments (Cuenca-Bescós et al. 2009).

The faunal diversity of Level 3 indicates that Cova Eirós is located in a rich and varied environment from the point of view of resources and landscape (ecotone) (Valverde 2019). The balance between forest or open areas species (cervids, bovids, equidae) and taxa from more rugged environments (caprids and chamois) may be indicative of the exploited territory by the Neanderthals, more open to the West and rugged to the East. These aspects are corroborated by the study of the small mammals of Level 3, where the presence of Microtus arvalis, Microtus agrestis and Microtus (Terricola) lusitanicus shows a predominance of forest and open wet habitats (Rey-Rodríguez et al. 2016). Few direct palaeobotanical data are available for Level 3, as pollen analyzes are ongoing. The anthracological study denotes an absolute predominance of Pinus sylvestris Linnaeus, 1753 (Martín Seijo 2013) and pollen studies of the marine, coastal and continental deposits of NW Iberia for this period indicate an alternation in the expansion of the mixed forest (deciduous Quercus) during interstadials with that of the semi-desert vegetation for the stadial phases (Artemisia, Chenopodiaceae and Ephedra distachya (Linnaeus, 1753) (Sánchez Goñi et al. 2008; Harrison \& Sanchez Goñi 2010; Fletcher et al. 2010). Glacial and periglacial studies in the NW point out that in the final moments of MIS3 moisture increases and glaciers reach their maximum extension (Pérez Alberti et al. 2011; Oliva et al. 2019). Summing up, paleoclimatic approaches and radiometric dating place Level 3 occupations in interstadial phases of MIS 3 (GI 11-GI 10), with annual average temperatures lower than nowadays' but greater rainfall, with a trend towards cooler conditions (Rey-Rodríguez et al. 2016; Viana-Soto \& Pérez-Alberti 2019).

\section{The hominin occupations of Level 3}

The technological and zooarchaeological features of the Level 3 point to repeated short-term occupations by Neanderthal groups at Cova Eirós, alternating with the use of the cavity by bears and carnivores as a place of hibernation, breeding and den. Although there is little evidence of a direct competition between human groups and carnivores or ursids (Valverde 2019) (Fig. 5), human occupations are a factor of concurrence and pressure upon those cave animals (González-Fortes et al. 2016; Romandini et al. 2018). Anthropogenic cutmarks on Ursus spelaeus and Panthera leo spelaea (Goldfuss, 1810) remains show that despite the alleged carnivore/human alternation in the habitat, at Cova Eirós Neanderthal groups were at the top of the trophic pyramid (Figs 4; 5). The presence of fauna belonging to different environments mark two clear mobility axes in terms of the foraging range of these Neanderthal groups: forested and mountainous environments. Moreover, the non-residential nature of occupations, the low density of artefacts, the spatial fragmentation of the chaînes operatoires and scarce evidences of lithic production (only on materials retrieved close by) are indicative of the high mobility of these communities.
Zooarchaeological studies and the noticeable presence of lithic points with evidence of their use as projectile elements underscore the hunting nature of the occupations (Lazuén Fernández et al. 2011). The diversity of species represented in the faunal record suggests the existence of mixed hunting strategies, without specialization in a particular species. The transport pattern is based on the selection of the nutritionally richer anatomical parts (heads and limbs), especially among larger animals. The importance of flakes with good dihedral edges for direct use and the presence of a quartzite cleaver could be related to the processing of carcasses in situ (TerradillosBernal \& Díez-Fernández-Lomana 2012; Claud et al. 2015). This statement is consistent with the traceological data, which identifies butchery activities related to the first processing of the animals such as dismemberment, carcass opening or butchering/defleshing (Lazuén Fernández et al. 2011). Thus, the larger percussive material could be linked to the faunal exploitation as evidenced by the high fragmentation of the bones and the frequency of cones and percussion flakes on the diaphyses. On the other hand, the typological diversity of the lithic assemblage and functional studies also point to the development of complementary domestic activities at the site, such as skin processing and woodworking (Lazuén Fernández et al. 2011; Márquez et al. 2017).

\section{THE LEVEL 2}

\section{Lithic assemblage}

The lithic material ascribed to Level 2 of Cova Eirós consists of 536 artefacts mostly belonging to the layer $2 \mathrm{~A}(\mathrm{n}=488)$. Xenomorphic quartz is the main raw material used (92\%), while automorphic quartz accounts for just 3\%. Other raw materials employed are quartzite $(5 \%)$, flint $(2 \%)$ and schist $(<1 \%)$ (Table 6$)$. The predominance of local raw materials is indicative of a low investment in terms of transportation by these groups. In sharp contrast, flint and automorphic quartz are only represented by retouched flakes, predetermining elements and no cortical products, indicating their greater mobility and that they are partially worked materials or blanks (quartz prisms) that these groups carry with them. While rare, their presence highlights a greater effort at source surveying since the natural occurrences of automorphic prisms within quartz dikes and chert linked to the Vegadeo Limestone Formation are scarce and/or have low perceptibility in the landscape (de LomberaHermida et al. 2016). The latter materials are linked to the production of the Upper Palaeolithic tool assemblage.

Knapping products predominate $(88 \%)$ over the elements linked to percussion $(2 \%)$, shaping $(3 \%)$ and exploitation (3\%) (Table 6). The different stages of the operative chains are only complete in xenomorphic and automorphic quartz. The presence of elements related to percussion activities is limited $(\mathrm{n}=12,2 \%)$ and only two of them show clear stigmas. For these percussion elements, quartz and quartzite from the immediate surroundings, with average dimensions between 52 and $67 \mathrm{~mm}$ long, are mainly used. Surprisingly, given the relative abundance of bipolar-on-anvil products in the assemblage, neither anvils nor hammerstones linked to this percussion technique were reported. 
TABLE 6. - Lithic assemblage from the Level 2 of Cova Eirós according to their lithic category and raw material. Bold: totals and subtotals.

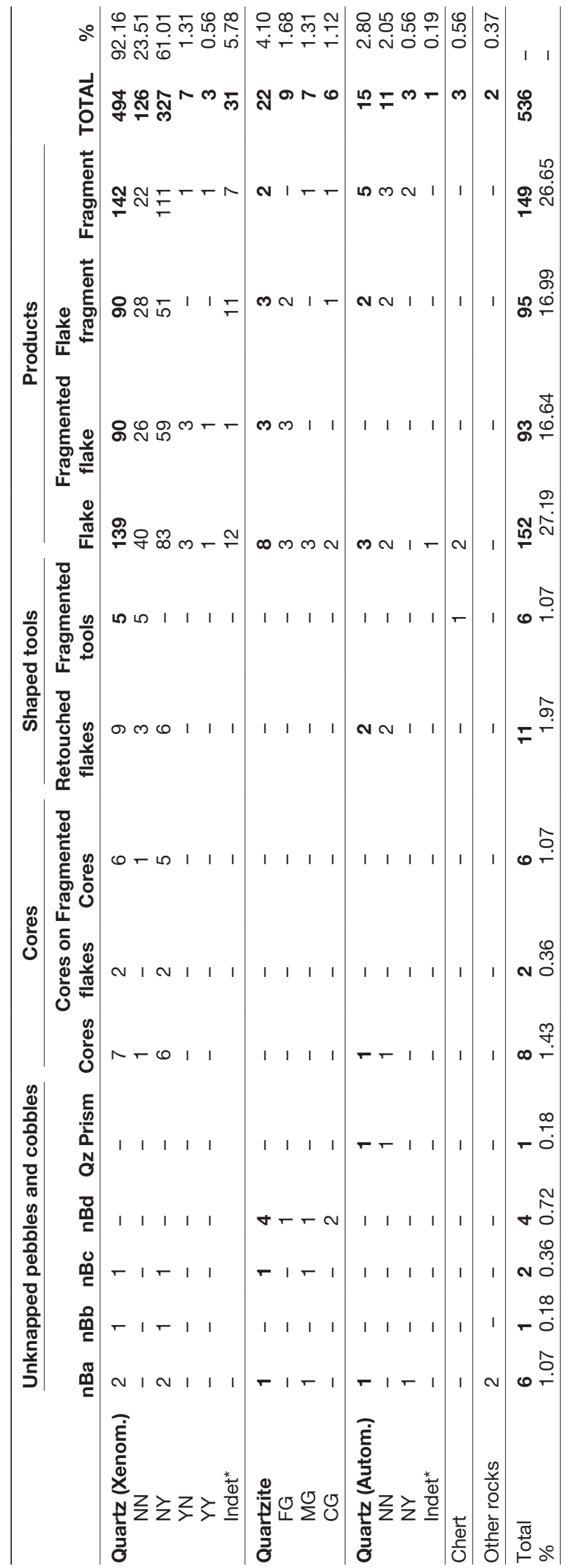

Cores at Level 2 are scarce $(n=10)$ and defined by their small size. They are exclusively on xenomorphic quartz, with just one made of an automorphic quartz prism. This fact, together with the large representation of knapping debris and the presence of cortical surfaces on flakes endorse the interpretation of in situ knapping of local xenomorphic quartz. The knapping strategies correspond to two types of productions: xenomorphic quartz (mainly from the NY group) and quartzite aimed at flake production, being dominant. The second type, less abundant, focuses on the production of bladelets.

The reduction methods are characterized by their expedient nature, focused on the production of flakes by bipolar-on-anvil technique $(n=5)$ and longitudinal and orthogonal strategies $(\mathrm{n}=2)$. In a technological context defined by the low supply and technological investment, the application of the bipolar reduction constitutes a strategy to maximize raw material and recycle flakes or cores for production (i.e., de la Peña Alonso 2015). The presence of discoidal knapping is hardly attested by a few flakes. The application of expedient knapping strategies and bipolar reduction is aimed at obtaining small and microformats, not exceeding $60 \mathrm{~mm}$ of maximum length. The small dimension of the flakes in xenomorphic quartz $(15.7 \times 15.1 \times$ $5.9 \mathrm{~mm}$ in average) stands out, while the quartzite flakes are wider than long $(27.5 \times 41.5 \times 12 \mathrm{~mm})$. As such, there is a strong tendency in the lithic collection of Level 2 towards miniaturization, especially among the xenomorphic quartz items (Pargeter 2016). Unlike other Upper Palaeolithic sites, the bipolar-on-anvil strategy is not focused on the production of bladelets (Klaric 2009) but in the making of small flakes, characterized by their crushed lineal and punctiform striking platforms (7\% and $9 \%$ of the flakes, respectively) (Fig. 6).

The production of bladelets is attested by a core and several products in automorphic quartz, flint and xenomorphic quartz (NN group). The production of bladelets in automorphic quartz is limited by the small size and mechanic properties of quartz prisms (Aubry et al. 2009; Rodríguez-Rellán 2016; Tardy et al. 2016). Thus, bladelets, with frequent distal knapping fractures, do not go beyond $30 \mathrm{~mm}$ long by $8 \mathrm{~mm}$ wide.

Shaped tools are scarce (2\%), made on xenomorphic quartz, automorphic quartz and flint (a retouched fragment). Interestingly, no retouched objects in quartzite have been recovered. There are two groups among the retouched flakes: notches, denticulate, side scrapers, burin and becs, made on the blanks of large flakes with no cortical surfaces and in xenomorphic quartz of the NY group; on the other hand, the few truncated and backed bladelets, are made of automorphic quartz and xenomorphic quartz of the NN group. The absence of retouching flakes in automorphic quartz suggests that these objects were introduced already worked to the site. Therefore, the typological variety of the retouched flakes in Level 2 is restricted and dependent on the weight of the so-called "substrate tools".

The lithic assemblage from Level 2 is hardly diagnostic when compared to other collections of the Cantabrian Upper Palaeolithic. It is defined by the predominance of xenomorphic quartz, the application of bipolar-on-anvil technique and expedient freehand knapping strategies plus 
A
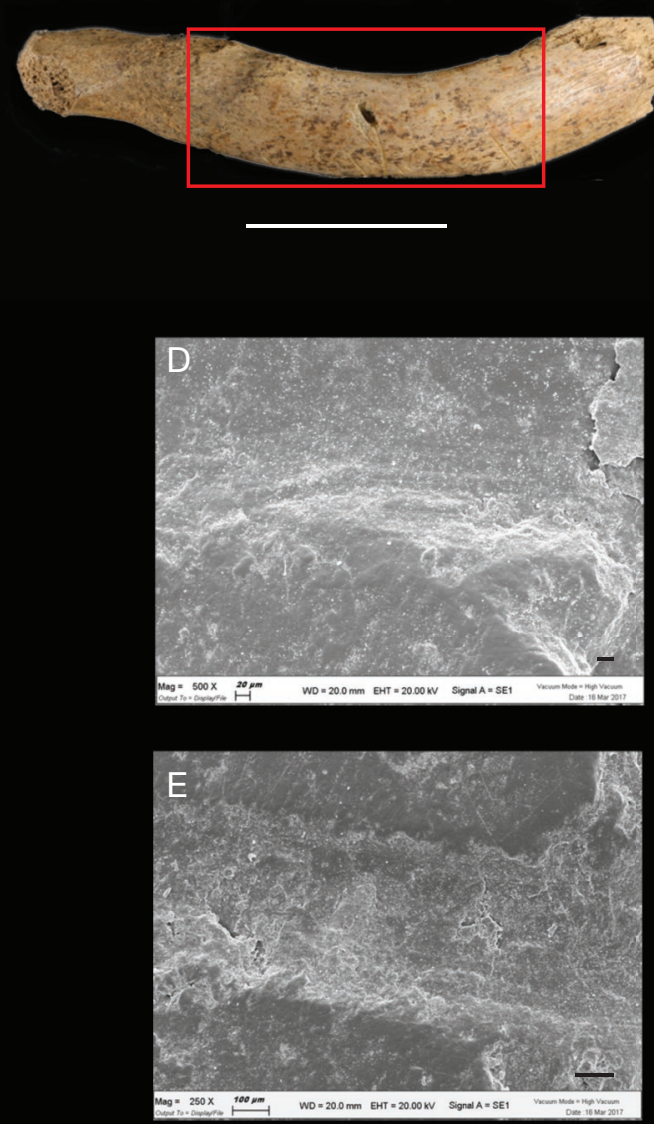

I

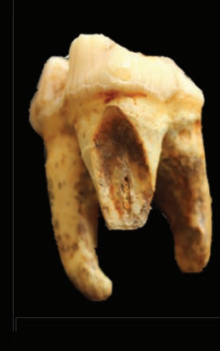

B
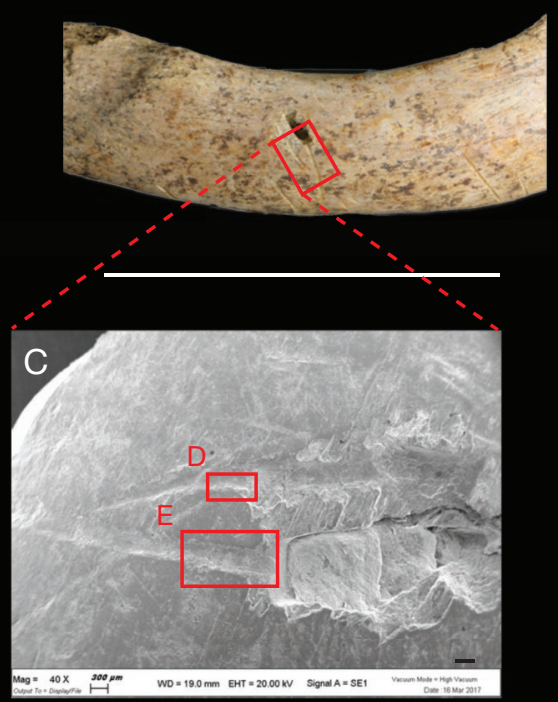

$\mathrm{F}$
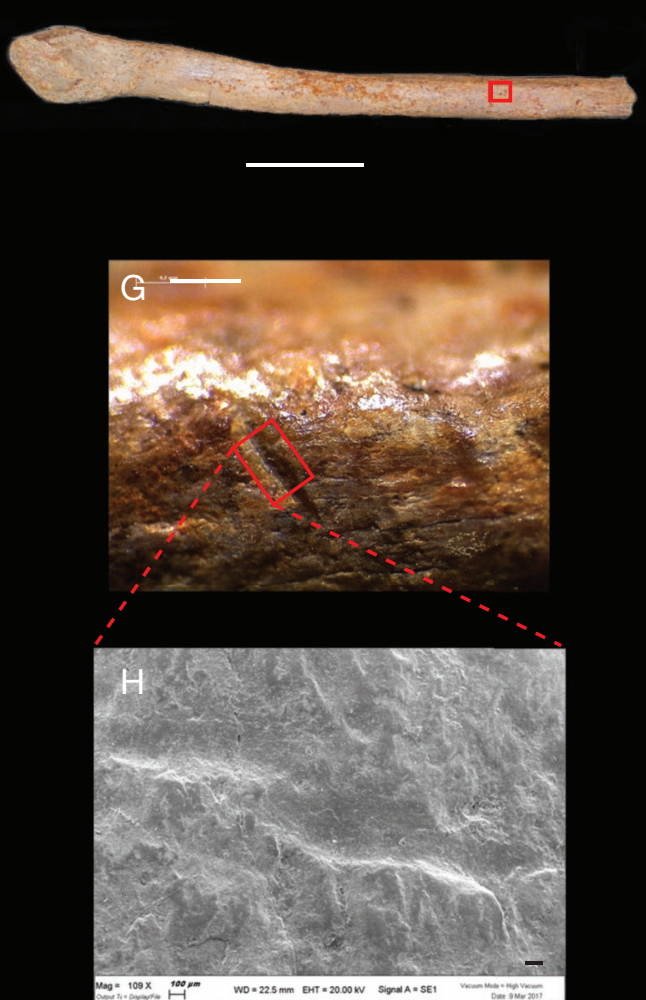

FIG. 5. - A, B, Ursus spelaeus Rösenmuller-Heinroth, 1794 rib with cutmarks; C-E, details of the cutmarks under ESEM; F, Ursus spealeus fibula showing defleshing marks; G, H, details under binocular stereo microscope and ESEM; I, J, Ursus spelaeus M2 with deliberate anthropogenetic marks. Scale bars: A, G,

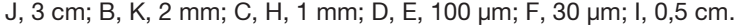

scarce typological standardization. However, there are two qualitative aspects that depart from the Middle Palaeolithic industries: there is a diversification of the lithological repertoire by incorporating exotic raw materials such as automorphic quartz and flint; it is remarkable, too, the occurrence of bladelets. Although the microlaminar production is only attested by a core and some products, it is a significant component, choosing those raw materials of greater quality and homogeneity (the automorphic quartz and the xenomorphic quartz of the NN group) (Fig. 6). 
TABLE 7. - Number of identified specimens (NISP), percentage of the number of identified specimens (\%NISP), minimum number of elements (MNE), expected minimum number of elements (eMNE), and minimum number of individuals (MNI) of the main taxonomic groups identified at Level 2 from Cova Eirós. Bold: totals and subtotals.

\begin{tabular}{|c|c|c|c|c|c|}
\hline Taxa & NISP & $\%$ NISP & MNE & eMNE & MNI \\
\hline $\begin{array}{l}\text { Ursus spelaeus (Rösenmuller- } \\
\text { Heinroth, 1794) }\end{array}$ & 102 & 38.05 & 101 & 2250 & 14 \\
\hline Ursus arctos (Linnaeus, 1758) & 6 & 2.23 & 6 & 184 & 2 \\
\hline $\begin{array}{l}\text { Panthera pardus (Linnaeus, } \\
\text { 1758) }\end{array}$ & 4 & 1.49 & 4 & 60 & 1 \\
\hline $\begin{array}{l}\text { Lynx pardina (Temminck., } \\
\text { 1827) }\end{array}$ & 2 & 0.74 & 2 & 74 & 1 \\
\hline Canis lupus (Linnaeus, 1758) & 11 & 4.1 & 10 & 162 & 2 \\
\hline $\begin{array}{l}\text { Vulpes vulpes (Linnaeus, } \\
1758 \text { ) }\end{array}$ & 2 & 0.74 & 2 & 74 & 1 \\
\hline $\begin{array}{l}\text { Meles meles (Linnaeus, } \\
\text { 1758) }\end{array}$ & 1 & 0.37 & 1 & 60 & 1 \\
\hline $\begin{array}{l}\text { Coelodonta antiquitatis } \\
\text { (Blumenbach, 1807) }\end{array}$ & 2 & 0.74 & 2 & - & 1 \\
\hline Equus ferus (Boddaert 1784) & 2 & 0.74 & 2 & - & 2 \\
\hline $\begin{array}{l}\text { Cervus elaphus Linnaeus, } \\
1758\end{array}$ & 37 & 13.8 & 29 & 134 & 3 \\
\hline $\begin{array}{l}\text { Capreolus capreolus } \\
\text { (Linnaeus, 1758) }\end{array}$ & 17 & 6.34 & 16 & 204 & 4 \\
\hline Bison priscus (Bojanus, 1827) & 3 & 1.1 & 3 & 5 & 2 \\
\hline $\begin{array}{l}\text { Bos primigenius (Bojanus, } \\
1827 \text { ) }\end{array}$ & 2 & 0.74 & 2 & - & 1 \\
\hline $\begin{array}{l}\text { Capra pyrenaica (Schinz, } \\
\text { 1838) }\end{array}$ & 2 & 0.74 & 2 & - & 1 \\
\hline $\begin{array}{l}\text { Rupicapra rupicapra } \\
\text { (Linnaeus, 1758) }\end{array}$ & 22 & 8.2 & 11 & 156 & 4 \\
\hline $\begin{array}{l}\text { Oryctolagus cuniculus } \\
\text { (Linnaeus, 1758) }\end{array}$ & 5 & 1.86 & 5 & - & 1 \\
\hline $\begin{array}{l}\text { Lepus europeus (Pallas, } \\
1778 \text { ) }\end{array}$ & 3 & 1.1 & 3 & - & 1 \\
\hline Marmota sp. & 1 & 0.37 & 1 & - & 1 \\
\hline Total & 224 & 100 & 202 & 3365 & 43 \\
\hline
\end{tabular}

The scarcity of the lithic assemblage and the absence of diagnostic elements from a typological point of view (Dufour bladelets, etc.) does not allow the assignment of this archeological level to any of the technocomplexes defined within the Aurignacian. Therefore, the ascription of the Level 2 collection to the (Evolved) Aurignacian is based on the presence -although testimonial- of the laminar knapping and on the numerical dates.

\section{Zooarchaeology}

1122 faunal remains were recovered from Level 2: 268 of them $(24 \%)$ have been specifically assigned to a minimum number of 18 taxa. Among those without anatomical identification, 639 fragments (57\%) were classified by weight size. Taking into account the NISP, the species with the highest representation is Ursus spelaeus (12\%), followed by Cervus elaphus (4\%) and Rupicapra rupicapra (3\%) (Table 7). The rest of the taxa have a very low presence, barely reaching ten anatomical remains, except Capreolus capreolus (NISP = 17). Regarding the presence of carnivores, the only species that has a NISP $>10$ is Canis lupus Linnaeus, 1758 (NISP = 11).

The MNE of Level 2 is 418, underlining the widespread prevalence of the cranial skeleton (18\%), metapodia (16\%) and axial skeleton (13\%), followed by upper appendicular members $(7 \%)$, lower $(3 \%)$ and hips $(3 \%)$. This anatomical representation pattern, with few remains of the appendicular skeleton, is also present in the MNE distribution by weight sizes (except for the small-size category). The skeletal representation of the MNE by weight sizes and by species has a similar pattern, with a predominance of cranial, axial and phalangeal remains. Among the Ursus spelaeus bones, there is a notable difference between the proportion of cranial (13\%) and axial (5\%) remains and the rest of the anatomical parts; the percentage of phalanges is $4 \%$ while the upper appendicular skeleton does not reach $2 \%$. On the other hand, the representation of this species is the highest of this level ( $24 \%$ of the total).

The MNI of Level 2 corresponds to 54 individuals. The predominant species is Ursus spelaeus, with a total of 15 individuals (28\% of those identified). Capreolus capreolus and Rupicapra rupicapra have 4 individuals respectively (7\%) and Cervus elaphus has an NMI = $3(6 \%)$. Bison priscus (4\%) and Equus sp., (4\%) have two individuals each. Among carnivores, only Canis lupus has more than one individual (4\%). Regarding the age of death of individuals, young adults (44\%) and neonates $(28 \%)$ predominate, followed by sub-adults $(26 \%)$. A single senile individual of Ursus spelaeus has been identified.

The faunal record of Level 2 has a high rate of fragmentation (96\%). Only $3 \%$ of the remains maintain $2 / 3$ of its original size and those exceeding $10 \mathrm{~cm}$ in length do not reach $1 \%$. Leaving aside the teeth, which generally show a better preservation, only 31 bone remains are complete ( $3 \%$ of the total NR). As for the average dimensions of the fragments, about $7 \%$ have a maximum length between $20-45 \mathrm{~mm}$. The remains measuring between $45-70 \mathrm{~mm}$ are the most represented, with $9 \%$ of the total, followed by fragments between 70-100 $\mathrm{mm}$ (less than $2 \%$ of the total) and finally the fragments whose maximum length exceeds $100 \mathrm{~mm}$ are only $0.65 \%$ of the sample.

Faunal remains with cut marks represent 3\% of the total $(\mathrm{n}=37)$. The size distribution of the cut marks shows greater presence among the remains of small size (41\%), followed by medium size $(22 \%)$ and large $(22 \%)$. From a taxonomic perspective, the distribution of cut marks is concentrated among ungulates (11\%) of large, medium and small sizes: Bos primigenius (Bojanus, 1827), Cervus elaphus, Capra pyrenaica Schinz, 1838 and Rupicapra rupicapra. It is important to remark the finding of a group of incisions on a phalanx of Panthera pardus Linnaeus, 1758.

In determining the existence and degree of anthropic activity on a faunal collection, the processes of intentional fragmentation by hominids in order to access the marrow are considered: 115 remains (NR) of the Level 2 show modifications related to this activity and we have identified percussion cones $(44 \%)$, cortical flakes (30\%), pressure fractures $(8 \%)$, percussion impacts $(8 \%)$, parasitic splinters $(6 \%)$ and medullary flakes $(2 \%)$. Carnivorous activity has been observed there in $10 \%$ of the total NR $(\mathrm{NR}=116)$. We have identified marks attributed to the corrosive action of salivary enzymes (27\%), crenulated edges (17\%), digested remains $(21 \%)$, imprints $(12 \%)$, grooves $(10 \%)$ and depressions (8\%) (Fig. 7). 


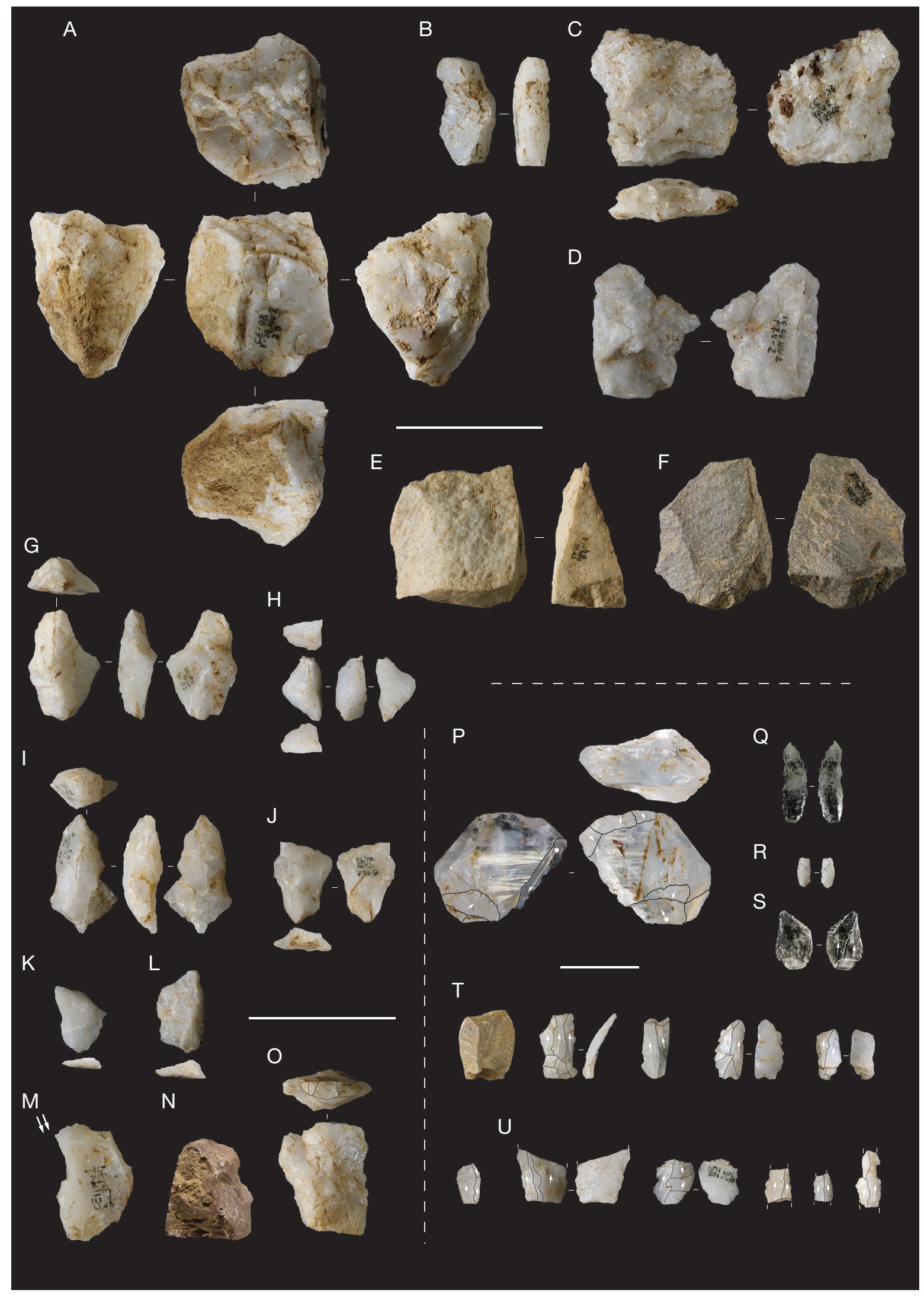

FIG. 6. - Lithic industry form Level 2: A, multifacial, multipolar core on quartz; B-D, quartz flakes; E, F, quartzite flakes; G-L, bipolar cores and flaking products on quartz; M, burin on quartz; $\mathbf{N}$, notch on chert; $\mathbf{O}$, truncated flake on quartz; $\mathbf{P}$, core on automorphic quartz; $\mathbf{Q}$, bladelet on automorphic quartz; R, fragmented bladelet on xenomorphic quartz; $\mathbf{S}$, truncated bladelet on automorphic quartz; T, bladelets on chert and xenomorphic quartz; $\mathbf{U}$, proximal and mesial fragments of bladelets on xenomorphic quartz. Scale bars: A-O, $5 \mathrm{~cm} ; \mathrm{P}-\mathrm{U}, 2 \mathrm{~cm}$. 
TABLE 8. - Representation of the number of identified specimens (NISP), minimum number of individuals (MNI) and the percentage of the MNI (\%) for the small vertebrates from Level 2 of Cova Eirós. Bold: totals and subtotals.

\begin{tabular}{lrrr}
\hline Taxa & NISP & MNI & $\%$ \\
\hline Rana temporaria (Linnaeus, 1758) & 5 & 5 & 6.76 \\
Vipera sp. & 3 & 1 & 1.35 \\
Rodentia indet. & 5 & 0 & 0.00 \\
Apodemus sylvaticus (Linnaeus, 1758) & 8 & 4 & 5.41 \\
Arvicola amphibius (Linnaeus, 1758) & 12 & 7 & 9.46 \\
Chionomys nivalis (Martins, 1842) & 4 & 3 & 4.05 \\
Microtus (Terricola) lusitanicus (Gerbe, 1879) & 25 & 16 & 21.62 \\
Microtus agrestis (Linnaeus, 1761) & 15 & 8 & 10.81 \\
Microtus arvalis (Pallas, 1779) & 33 & 18 & 24.32 \\
Microtus arvalis-agrestis (Pallas, 1779/ & 5 & 4 & 5.41 \\
$\quad$ Linnaeus, 1761) & & & \\
cf. Miniopterus sp. & 1 & 1 & 1.35 \\
Chiroptera indet. & 1 & 1 & 1.35 \\
Rhinolophus ferrumequinum (Schreber, 1774) & 1 & 1 & 1.35 \\
Sorex sp. & 2 & 2 & 2.70 \\
Talpa cf. occidentalis (Cabrera, 1907) & 1 & 1 & 1.35 \\
Erinaceus europaeus (Linnaeus, 1758) & 2 & 2 & 2.70 \\
\hline Total & $\mathbf{1 2 3}$ & $\mathbf{7 4}$ & 100.00 \\
\hline
\end{tabular}

TABLE 9. - Values of temperature and precipitation for the Level 2 of Cova Eirós derived from the Mutual Climatic Range method and the Bioclimatic Model. Abbreviations: MAP, mean annual precipitation; MAT, mean annual temperature; Max, maximum of values obtained; Min, minimum of values obtained; MTC, mean temperature of coldest month; MTW, mean temperature of warmest month; SD, standard deviation of values obtained; $\boldsymbol{\Delta}$, difference between the values obtained by analysing the small mammals from Cova Eirós and current values.

\begin{tabular}{lcc}
\hline & Mutual Ecogeographic Range & Bioclimatic model \\
\hline MAT & 7.69 & 8.58 \\
SD & 1.60 & 3.39 \\
Max & 10 & - \\
Min & 5 & - \\
$\Delta$ & -3.41 & -2.52 \\
MTW & 16.08 & 18.13 \\
SD & 1.04 & 4.77 \\
Max & 18 & - \\
Min & 15 & - \\
$\Delta$ & -1.02 & 1.03 \\
MTC & 1.15 & -0.3 \\
SD & 1.34 & 4.66 \\
Max & 4 & - \\
Min & 0 & - \\
$\Delta$ & -4.75 & -6.2 \\
MAP & 1738 & 1332 \\
SD & 444 & 533 \\
Max & 2500 & - \\
Min & 800 & - \\
$\Delta$ & 705 & 299 \\
\hline
\end{tabular}

According to the zooarchaeological analysis, the anthropic management of faunal resources corresponds to a model of exploitation of small, medium and large carcasses with a predominance of cranial and appendicular elements, especially metapods and phalanges. There are certain differences in the anatomical representation between ungulates and carnivores, in addition to differences in weight sizes. Carnivores have an anatomical profile based on cranial elements, especially teeth. Ungulates have a more varied MNE, in which cranial remains, femur, ulna and metapods stand out. By weight size, most of the categories have a high percentage of teeth, cranial and appendicular remains. The strong fracture index in fresh, especially in diaphysis of long bones indicates a very intensive use of the carcasses, common to all weight categories. The distribution and frequency of the cut marks shows that several processing activities of the faunal remains were developed in the cave, such as skinning, evisceration or butchering. Finally, a $U$. spelaeus decidual canine showing man made wear in the internal face, indicates an anthropic modification whose intentionality is uncertain (Fábregas Valcare et al. 2012) (Fig. 7D). In addition to the hominins, the carnivores acted as modifying agents of faunal remains in Level 2 and bites, diaphyseal cylinders, grooves, imprints and depressions have been identified. The frequency and dimensions of the teeth marks allow to establish the small and medium size of the predators.

\section{Small mammals and palaeoenvironmental reconstruction}

The most abundant species in this level are the common vole (Microtus arvalis 24\%), the Lusitanian pine vole (Microtus (Terricola) lusitanicus 22\%), the field vole (Microtus agrestis $11 \%$ ) and the northern water vole (Arvicola amphibius; 10\%) (Table 8). The small vertebrates Vipera sp., cf. Miniopterus sp. and Erinaceus europaeus are represented only in the Level 2.

Regarding the palaeoclimatic conditions, Mutual Ecogeographic Range (MER) (Blain et al. 2016) and the Bioclimatic Model (BM) (Hernández Fernández 2001; Hernández Fernández et al. 2007) yield results suggesting that the precipitation was higher and the temperatures lower than nowadays (Table 9).

The palaeoenvironmental reconstruction, as shown by the Habitat Weighting method (Evans et al. 1981; Andrews 2006; modified by Blain et al. 2008; López-García 2011), suggests a mixture of woodland and open humid habitats, but there is also a significant proportion of rocky areas found in both levels (2 and 3). According to the data obtained from small vertebrates, during the hominin occupations of Level 2 the main types of habitats are woodland (47\%) followed by open humid (32\%), reflecting the species found in this level, such as Microtus arvalis, Microtus agrestis and Microtus (Terricola) lusitanicus. The other types of habitats are rocky $(14 \%)$, open dry $(6 \%)$ and water $(2 \%)$.

Palaeoclimatic reconstruction and numerical dating place Level 2 occupations at interstadial phases of MIS3 (GI7-GI6), with annual average temperatures lower than today's, but greater rainfall (Rey Rodríguez et al. 2016). The palynological studies of the marine, coastal and continental deposits of the Iberian Northwest for this period indicate a shift from the mixed forest expansion (deciduous Quercus) during the interstadials to the semi-desert vegetation for the stadials (Artemisia, Chenopodiaceae and Ephedra distachya) (Fletcher \& Sánchez Goñi 2008; Sánchez Goñi et al. 2008; Harrison \& Sánchez Goñi 2010; Ramil-Rego et al. 2010). Glacier studies in the NW of the Iberian Peninsula stipulate that during these final phases of MIS3, with remarkable moisture and cold conditions, glaciers still maintain their maximum extension (Pérez Alberti et al. 2011; Oliva et al. 2019). 


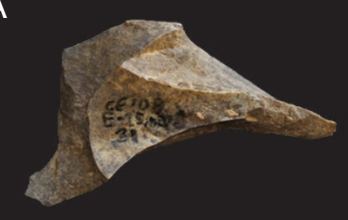

B

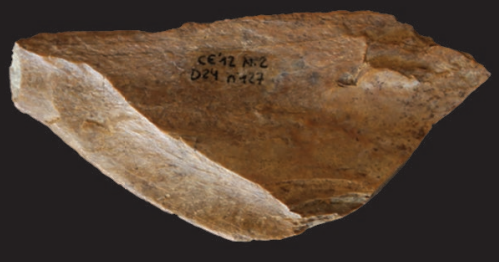

C

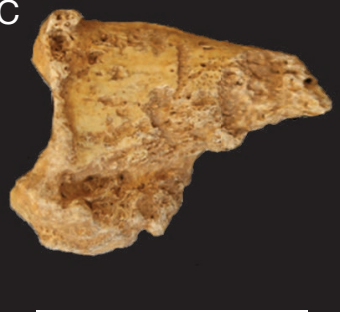

D

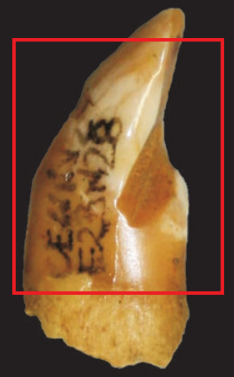

G

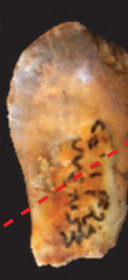

H

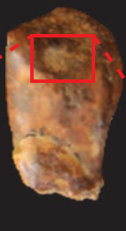

E

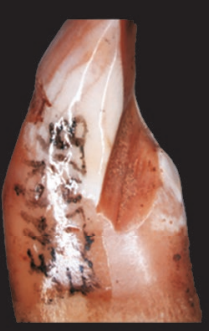

F

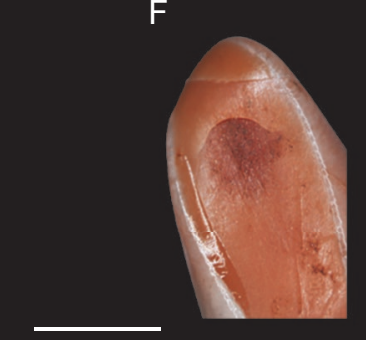

K

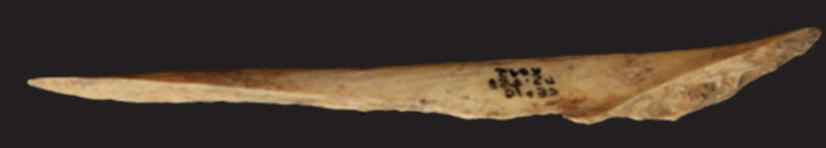

L
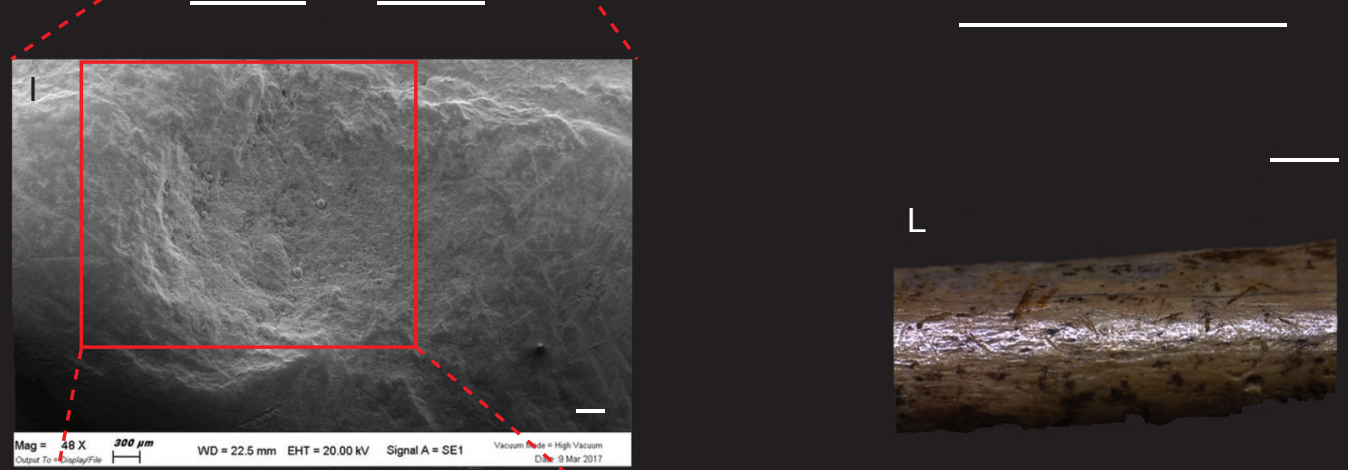

\section{Mag $=48 \times 100$}

WD $=22.5 \mathrm{~mm}$ EHT $=20.00 \mathrm{KV}$ Signal A $=\mathrm{SE}$

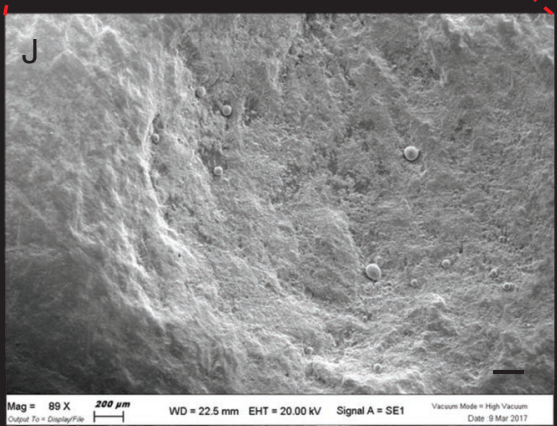

M

N
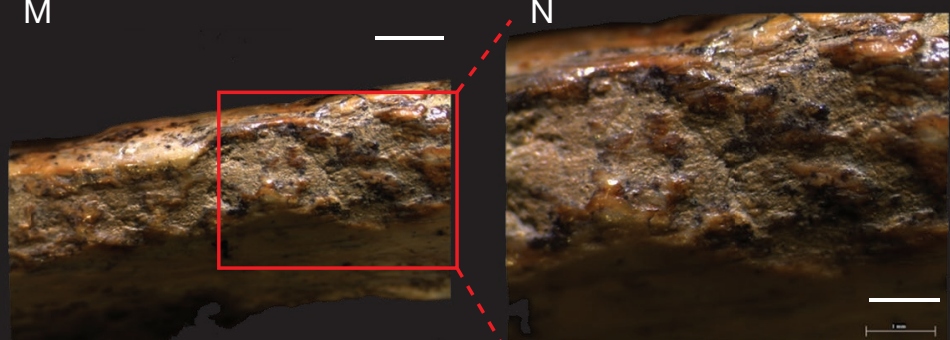

FIG. 7. - A, B, Anthropogenic bone breakage evidences; C, third phalanx of an Ursus spelaeus Rösenmuller-Heinroth, 1794 with carnivore marks; D-F, deciduous lower incisive of Ursus spelaeus showing working and abrasion marks in its lingual face; G, H, atrophic canine teeth of a Cervus elaphus Linnaeus, 1758 (buccal and lingual faces) with perforation marks and details under ESEM (I, J); K, ulna of a Cervus elaphus with possible anthropogenic marks; L, possible abrasion on the distal metaphysis under binocular stereo microscope; $\mathbf{M}, \mathbf{N}$, posible use marks. Photos: D-F, Marta Pérez Rama, Universidade de Coruña). Scale bars: A-C, $\mathrm{K}, 3 \mathrm{~cm}$; D, $1 \mathrm{~cm}$; E-H, $5 \mathrm{~mm}$; I, J, $300 \mu \mathrm{m} ; \mathrm{L}, \mathrm{M}, 2 \mathrm{~mm}$; N, $1 \mathrm{~mm}$. 


\section{The hominin occupations of Level 2}

Several features of the archaeological record of Level 2 indicate that the human occupations at Cova Eirós had little impact. The lithic management strategies (characterized by the transformation of immediate resources and the predominance of expedient reduction approaches), along with the low density of artefacts point to short and repeated visits to the cave by AMH. On the other hand, the presence of raw materials whose outcrops are located $15-20 \mathrm{~km}$ to the NEE (chert) and faunal remains corresponding to forested and mountainous environments hint at the exploitation of a wider economic territory.

The hunting strategies are not specialized in a particular species, although cervids (Cervus elaphus, Capreolus capreolus) and chamois predominate among the ungulates. In the lithic assemblage, the items that can be directly linked to hunting activities do not have an outstanding representation, but the abundance of small flakes with suitable cutting edges can be related to the processing of carcasses in situ, which is consistent with cutting and percussion marks found in the faunal assemblage, indicating butchering activities (Valverde 2019). Despite the high degree of fragmentation of the faunal remains, the percussive material of the lithic set is scarce and small in size and weight.

Therefore, the Level 2 occupations of Cova Eirós can be interpreted as opportunistic and seasonal visits, framed in a context of high logistic mobility (Binford 1978). This would facilitate the alternation of human and carnivorous occupations in the cavity. In fact, Level 2 shows the highest number of carnivore species and faunal remains. Although no direct interaction between humans and carnivores has been identified (except in the specific case of the Panthera pardus phalanx), the presence of bites and traces of digestion of bone elements may indicate secondary access by the carnivores to the faunal remains left behind by the humans (Valverde 2019).

\section{DISCUSSION}

The chronometry of levels 3 and 2 of Cova Eirós is relevant to the discussion about the Middle-Upper Palaeolithic transition in the Iberian Peninsula. According to the radiocarbon dates, the Neanderthal occupations on top of Level 3 took place at a late stage of MIS 3 and its lithic assemblage falls within the variability observed for the European Late Middle Palaeolithic sites (Rios Garáizar 2008; Carrión-Santafé et al. 2008; de la Torre et al. 2013). For northwest Iberia, the Middle Palaeolithic records are characterized by the use of local raw materials based on the management of xenomorphic quartz, the predominance of expedient, centripetal and discoidal exploitation strategies and the production of small retouched flakes (de Lombera Hermida et al. 2008, 2011; Aubry et al. 2016; Vaquero et al. 2018). The Levallois component in these assemblages is very restricted but is particularly associated to those quartzite varieties of better aptitude for knapping (i.e., fine-grained Armorican quartzite) (de Lombera Hermida 2005; Rodríguez-Álvarez et al. 2008; Matias 2016).
At a regional level, in relation to the Cantabrian Rim and the Atlantic Façade, these Mousterian occupations stand out for their location in mountain environments at medium-high altitude (reaching 800-1000 m above sea level, Thiébaut et al. 2012; Alcaraz-Castańo et al. 2017; Domingo et al. 2017). This shows similarities with other MIS 4-3 Iberian sites characterized by their short duration, seasonal nature and high mobility that lead to spatial fragmentation of the chaîne opératoire and transport of certain varieties of raw material. These patterns have been described in the Middle Palaeolithic occupations identified in levels B and D of Axlor (Rios-Garáizar 2012), Llonín (Sanchis et al. 2019), level 130 of Mirón (Marín-Arroyo et al. 2020) or upper levels of Esquilleu (Baena et al. 2012), as well as in other sites such as Teixoneres (Rosell et al. 2010, 2017) or Valdegoba (Terradillos-Bernal \& Díez FernándezLomana 2018), for example.

Although the chronological position of the Level 3 must be confirmed by further radiometric dates, the radiocarbon dating (OxA-30471) offers a range of 41.299-38.390 yrs cal BP (GS 12-GI 10). As stated before, this chronological ascription to MIS 3 is consistent with the small mammals and paleoenvironmental data, although future radiocarbon dates must be obtained for corroborating this hypothesis. In accordance with it, the Neanderthal occupations of the top of Level 3 of Cova Eirós, would post-date the last occurrence of the final Mousterian in the northern Iberian Peninsula (estimated around 47.8-44.8 kyrs cal BP, Higham et al. 2014; Marín-Arroyo et al. 2018) and would be contemporary to those estimated for the late Chatelperronian and the initial Aurignacian in the Cantabrian region (43.3-40.5 kyrs cal BP, Wood et al. 2014, 2016; Marín-Arroyo et al. 2018). As such, considering the Esquilleu sequence too (BaenaPreysler et al. 2019), Cova Eirós seems to corroborate the late survival of Neanderthal groups in mountain regions of North Iberia. The fluctuations of MIS 3 had an undoubted influence on Neanderthal populations (Melchionna et al. 2018), forcing them to adapt their subsistence and territorial strategies, as indicated by the intensification in the processing and caloric utilization of faunal resources (Hodgkins et al. 2016), the change from residential models to patterns of high logistic mobility, and the occupation of peripheral and mountainous areas, as the Level 3 of Cova Eirós also points at (Vaquero et al. 2006; Baena et al. 2012; BaenaPreysler \& Carrión-Santafé 2013).

As for the Early Upper Palaeolithic, the radiocarbon dating of Level 2 of Cova Eirós offers a chronological range between 35.3-34.7 kyrs cal BP (GI 7-6). These occupations would correspond to an advanced stage of the Aurignacian. However, it is difficult to establish a net differentiation between the early and evolved Aurignacian based only on typology, since in some cases the assemblages have few pieces, are ambiguous or come from ancient excavations (Bernaldo de Quirós \& Maíllo-Fernández 2009; Gutiérrez-Zugasti et al. 2018). Based on the study by Marín-Arroyo et al. (2018) on a large sample of Cantabrian Middle and Upper Palaeolithic sites, the dates of Level 2 of Cova Eirós are contemporary to other lithic assemblages assigned to the Evolved Aurignacian 


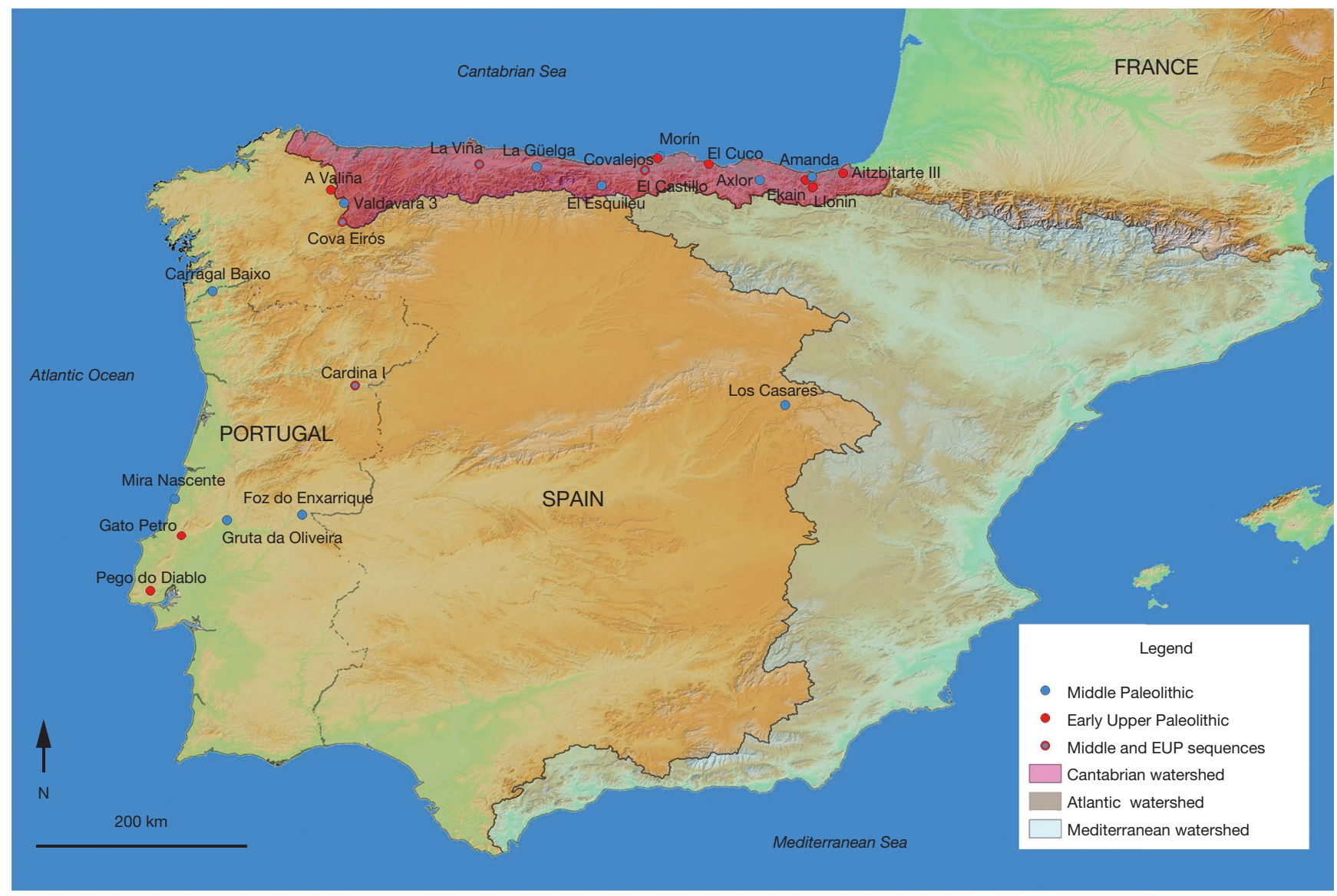

FIG. 8. - Location of the main Middle Palaeolithic and Early Upper Palaeolithic sites mentioned in the text and their relationship with the main Iberian watersheds.

(GI8-GS6) such as Ekain IXb, Atizbitarte III Vb and La Viña XII-XI. One point to consider is the altitude of Cova Eirós (785 $\mathrm{m}$ a.s.l.), since most Cantabrian sites are located at levels below $400 \mathrm{~m}$ a.s.l. which would indicate the occupation of mountainous spaces, at least on a seasonal basis, by these human groups during the early Upper Palaeolithic (Fig. 8).

This chronological framework offers interesting implications for the study of the first Upper Palaeolithic settlement in the northwest of the Iberian Peninsula. At the regional level, the numerical dates from the Cova Eirós Level 2 and the technological features of its lithic assemblage shed light on the cultural ascription of the close-by cave of A Valiña (Lugo, Galicia), defined by an expedient and ambiguous lithic assemblage. Initially ascribed to the early Upper Palaeolithic and Chatelperronian complex (Llana Rodríguez et al. 1996; Villar Quinteiro 1997), subsequent reviews considered it as possibly late Mousterian (Vaquero et al. 2006; Maíllo Fernández 2008). However, we must take into account the similarities between the lithic assemblages from A Valiña and the Level 2 of Cova Eirós, their occupation patterns and the absolute dating. If we consider the contemporaneity between the dates of Level 2 of Cova Eirós (Beta- 254280, Table 1) and the date directly linked to the level of hominin occupation of A Valiña (GrA-3014: $31600 \pm 250$ BP, 34.123-32.987 cal BP, Llana Rodríguez et al. 1996; Fernández Rodríguez 2000), the most parsimonious hypothesis is to reestablish its ascription to the initial Upper Palaeolithic (Aurignacian sensu lato). In addition, the radiometric date available for Level IV of A Valiña is far from the proposed chronological range for the Cantabrian Chatelperronian (42.4-41.4 kyrs cal BP, Marín-Arroyo et al. 2018). Thus, we might put forward that A Valiña and Level 2 of Cova Eirós are the only early Upper Palaeolithic evidences in NW Iberia.

The chronology and the location of these sites are key to understanding the tempo of the advance of $\mathrm{AMH}$ in western Iberia. An east-west progression has been proposed for their entry into the Cantabrian region, the first arrival being dated around 43.3-40.5 kyrs cal BP (Castillo, 16, Labeko Koba VII) (Wood et al. 2016; Marín-Arroyo et al. 2018). The move towards the west Cantabrian might be related to the demographic increase of these groups and their expansion during the advanced stages of the Aurignacian (Marín-Arroyo et al. 2018; Schmidt \& Zimmermann 2019). If we take into account the radiocarbon dating of A Valiña and Level 2 of Cova Eirós, the first evidence of the AMH in the Northwest would be at the end of GI7 or early GS7. In that sense, the small mammal data point to an interstadial of MIS 3, which, based on dating, would be more consistent with the GI7 (Rey-Rodríguez et al. 2016).

A Valiña and Cova Eirós are both located in the mountainous foothills bordering the inner depressions of Galicia, at medium altitude levels (400-800 $\mathrm{m}$ a.s.l.). Considering their 
location we could formulate some hypotheses about the routes of entry of modern humans in the NW of the Iberian Peninsula, always with the caution that the scarcity of archaeological sites demands (Fábregas-Valcarce \& de Lombera-Hermida 2010). One of the natural routes for the arrival into the NW would be along the Cantabrian Rim that reaches up to the Northeast of Galicia, and then gradually descending to the south by the periphery of the Cenozoic basins and the mountain ranges. The placement of Cova Eirós, in the Navia/Mińo interfluve, could indicate another possible direct route of penetration to the interior of the NW during the initial Upper Palaeolithic: the Navia Valley. Thenceforth the Miño valley makes way to the Atlantic shore but we must bear in mind, anyway, the high incidence of glacial and periglacial conditions at these mountain areas (Oliva et al. 2019).

The chronological and contextual data from the north of Portugal and the Atlantic Façade are more problematic due to the scarcity of sedimentary records and the high incidence of erosive processes (Aubry et al. 2006, 2011). In central Portugal the youngest Middle Palaeolithic site is recorded in the Lower Tejo River terrace T6, at Foz do Enxarrique -linked to cold and dry conditions and recently dated by OSL at $44 \pm 3$ kyrs (Cunha et al. 2019)- and the Mira Nascente coastal site dated also by OSL around 42-40 kyrs (Haws et al. 2010). Only for the case of Gruta de Oliveira (level 8), with dates around 37.1-35.7 kyrs cal BP (Angelucci \& Zilhão 2009) some coexistence with AMH could have taken place. Although some researchers defend the presence of groups ascribed to the Aurignacian II (or evolved Aurignacian) (Zilhão et al. 2010, 2017), other authors consider that the first settlement of Homo sapiens on the Atlantic Façade occurred in the initial moments of the Gravettian, around 33.5-33.0 kyrs cal BP (Bicho et al. 2015, 2017). Nevertheless, the recent dates from CardinaSalto do Boi point to the late survival of Neanderthal groups and an AMH arrival around 34.0-38.4 kyrs BP (OSL date) linked to an Aurignacian industry, at least for the north of Portugal (Aubry et al. 2019, 2020a, b; this volume). Finally, the recently published dates from Lapa do Picareiro, in central Portugal, suggest an early arrival of Homo sapiens in the Atlantic façade, around 41,1-38,1 Ka cal BP (Haws et al. 2020). The route of this entry is unclear. For the interior of the Iberian Peninsula, the arrival of AMH is not adequately contrasted neither in the inland Meseta until 25.5 ka cal BP (Alcaraz-Castaño et al. 2013, 2017) nor in the middle Tejo valley (Benedetti et al. 2019). In that sense, both the northwest and the Atlantic Façade do not show the immediate appearance of the AMH after the last Neanderthal occupations, instead a spatial and chronological gap seemingly existing in the north-south direction.

Therefore, the expansion of the AMH groups to the west and south of the Iberian Peninsula implies a mosaic model and does not seem to be so swift and should be linked to the conditions of the biogeographic changes and fluctuations that define the late MIS 3, especially in relation to the period between the interstadials GI8-GI7 and the expansion of steppe formations (Zilhão et al. 2010; Haws 2012).

\section{CONCLUSIONS}

The richness and chrono-stratigraphic definition of the archaeological record from Cova Eirós give a more complete vision about the technology and subsistence strategies of the last Neanderthal and the first AMH groups that occupied the Iberian northwest. The archaeological data, as defined by the exploitation of local raw materials, and the subsistence and settlement patterns reflect the flexibility of the late Middle and early Upper Palaeolithic groups regarding the lithological and geographical constraints of this land.

The chronological and palaeoenvironmental data help us to understand the relationship between the fluctuations of the human groups and the shifts of the climatic conditions. The radiometric data from the Level 3 indicate a late survival of Neanderthal groups (c. 40 kyrs cal BP) in the mountainous regions. After a first entry of the AMH to the west of the Cantabrian Rim (Nalón valley), dated 43.3-40.5 kyrs cal BP, the modern human groups linked to the Advanced Aurignacian probably did not occupy the caves of northwest Iberia (Cova Eirós and A Valiña) until the changes associated with the GI8 and GI7 (35.3-34.7 kyrs cal BP), but a more detailed dating strategy is sorely needed. The Upper Palaeolithic settlement of the westernmost part of Iberia will not take a firm hold until the arrival of the Gravettian groups, around $33.5 \mathrm{kyrs}$ cal BP. This preliminary interpretation is obviously conditioned by the existence of geographical gaps (west of the Asturian region and northern Portugal, territories lacking limestone formations), the different intensity of research and the scarcity of sedimentary deposits with extensive records belonging to this period. But new research from these regions will provide complementary information about the demise of the Neanderthal groups and its relationship to the dispersal of the Homo sapiens across the Iberian Peninsula.

\section{Acknowledgements}

The archaeological works at Cova Eirós have been funded by Consellería de Cultura da Xunta de Galicia (2015-2019) and Ministry of Science (PID2019-107480GB-I00). This research paper is a result of the Workshop "II Xornadas sobre o Paleolítico do Noroeste. De costa a costa: Os Territorios Paleolíticos entre as beiras cantábrica e atlántica" held in Triacastela in 2017 and funded by Xunta de Galicia and GDR Ribeira Sacra-Courel. Rey-Rodriguez is beneficiary of a PhD scholarship funded by the Erasmus Mundus Program (IDQP). X.P. Rodríguez-Alvarez research is also supported by the AGAUR (SGR 2017-1040) and the URV (2019PFR-URV-91) projects. The Institut Català de Paleoecologia Humana i Evolució Social (IPHES) has received financial support from the Spanish Ministry of Science and Innovation through the "María de Maeztu" program for Units of Excellence (CEX2019-000945-M). This work was also funded by the Fundação para a Ciência e Tecnologia (FCT), through: 1) National funds, from the project UIDB/ MAR/04292/2020 — MARE; and 2) a Sabbatical grant (ref. SFRH/BSAB/150395/2019) held by Pedro P. Cunha (Programa Operacional Capital Humano). Joel Carvalho helped in the Sedimentology Laboratory-University Coimbra. 


\section{REFERENCES}

Alcaraz-Castaño M., Alcolea González J., De Balbín Behrmann R., García Valero M. Á., Yravedra Sainz de los Terreros J. \& Baena Preysler J. 2013. - Los orígenes del Solutrense y la ocupación pleniglaciar del interior de la Península Ibérica: Implicaciones del nivel 3 de Peña Capón (valle del Sorbe, Guadalajara). Trabajos de Prehistoria 70: 28-53. https:// doi.org/10.3989/tp.2013.12101

Alcaraz-Castaño M., Alcolea-González J., Kehl M., Albert R. M., Baena-Preysler J., De Balbín-Behrmann R., Cuartero F., Cuenca-Bescós G., Jiménez-Barredo F., LópezSÁez J. A., Piqué R., Rodríguez-Antón D., Yravedra J. \& Weniger G. C. 2017. - A context for the last Neandertals of interior Iberia: Los Casares cave revisited. PLoS ONE: e0180823. https://doi.org/10.1371/journal.pone.0180823

ANDREWS P. 2006. - Taphonomic effects of faunal impoverishment and faunal mixing. Palaeogeography. Palaeoclimatology. Palaeoecology 241: 572-589. https://doi.org/10.1016/j. palaeo.2006.04.012

AngeluCCI D. E. \& ZILHÃo J. 2009. — Stratigraphy and formation processes of the Upper Pleistocene deposit at Gruta da Oliveira, Almonda karstic system, Torres Novas, Portugal. Geoarchaeology 24: 277-310. https://doi.org/10.1002/gea.20267

Aubry T., Almeida M. \& Neves M. J. 2006. — The Middle-toUpper Paleolithic transition in Portugal: an Aurignacian phase or not?, in Ofer Bar-Yosef O. \& ZilHĀo J. (eds), Towards a Definition of the Aurignacian - Proceedings of the Symposium Held in Lisbon, Portugal, June 25-30, 2002. Instituto Português de Arqueologia: 95-108.

Aubry T., Mangado X. \& Davide Sampaio J. 2009. - Os artefactos: reconstituição da funcionalidade e da dinâmica de formaçáo dos sítios. Estudo do aprovisionamento em matériasprimas., in Aubry T. (ed.), 200 Séculos Da História Do Vale Do Côa: Incursōes Na Vida Quotidiana Dos Caçadores-Artistas Do Paleolítico. IGESPAR, IP, Lisboa: 131-170.

Aubry T., Dimuccio L. A., Almeida M., Neves M. J., AngeLUCCI D. E. \& CUNHA L. 2011. — Palaeoenvironmental forcing during the Middle-Upper Palaeolithic transition in centralwestern Portugal. Quaternary Research 75: 66-79. https://doi. org/10.1016/j.yqres.2010.11.002

Aubry T., Barbosa A. F., Luís L., Santos A. T. \& Silvestre M. 2016. - Quartz use in the absence of flint: Middle and Upper Palaeolithic raw material economy in the Côa Valley (Northeastern Portugal). Quaternary International 424: 129-133. https:// doi.org/10.1016/j.quaint.2015.11.067

Aubry T., Barbosa A. F., Gameiro C., Luís L., Santos A. T. \& SilvestRe M. 2019. - Cardina I - Salto do Boi: cinco metros de arquivo da ocupação paleolítica no Vale do Côa. Côavisão 21: 63-74.

Aubry T., Dimuccio L. A., Barbosa A.F., Luís L., Santos A. T., Silvestre M., Thomsen K. J., Rades E., Autzen M. \& MurRAY A. S. 2020a. - Timing of the Middle-to-Upper Palaeolithic transition in the Iberian inland (Cardina-Salto do Boi, Côa Valley, Portugal). Quaternary Research 98: 81-101. https://doi. org/10.1017/qua.2020.43

Aubry T., Santos A. T., Luís L., Barbosa A. F. \& Silvestre M. 2020b. - Dynamiques fluviales et occupation humaine paléolithique : nouvelles données de la vallée du Côa (Portugal) Fluvial Dynamics and Palaeolithic Settlement: new data from the Côa Valley (Portugal). Comptes rendus Palevol 19 (7): 117-135. https://doi.org/10.5852/cr-palevol2020v19a7

Baena J., Carrión E., Cuartero F. \& Fluck H. 2012. - A chronicle of crisis: The Late Mousterian in north Iberia (Cueva del Esquilleu, Cantabria, Spain). Quaternary International 247: 199-211. https://doi.org/10.1016/j.quaint.2011.07.031

Baena-Preysler J. \& Carrión-Santafé E. 2013. - Marriage between relatives: a discussion of Mousterian survival in the
Iberian Peninsula, in Pastoors A. \& Auffermann B. (eds), Pleistocene Foragers on the Iberian Peninsular: Their Culture and Environmental. Festchrift in Honour of Gerd-Christian Weniger for His Sixtieth Birthday. Wissenschaftliche Schriften des Neanderthal Museums, Mettman: 123-142.

Baena-Preysler J., Carrión Santafé E., Torres Navas C. \& VAQUERO RodríGUEZ M. 2019. - Mousterian inside the upper paleolithic? The last interval of El Esquilleu (Cantabria, Spain) sequence. Quaternary International 508: 153-163. https://doi. org/10.1016/j.quaint.2018.11.015

Benedetti M. M., Haws J. A., Bicho N. F., Friedl L. \& Ellwood B. B. 2019. - Late Pleistocene site formation and paleoclimate at Lapa do Picareiro, Portugal. Geoarchaeology 34: 698-726. https://doi.org/10.1002/gea.21735

Bernaldo De Quirós F. \& Maíllo-Fernández J. M. 2009. The Transitional Aurignacian and the Middle-Upper Palaeolithic Transition Model in Cantabrian Iberia, in CAMPS M. \& Chauhan P. R. (eds), Sourcebook of Paleolithic Transitions. Methods, Theories and Interpretations. Springer-Verlag, New York: 341-360.

Bicho N., Marreiros J., Cascalheira J., Pereira T. \& Haws J. 2015. - Bayesian modeling and the chronology of the Portuguese Gravettian. Quaternary International 359-360: 499-509. https://doi.org/10.1016/j.quaint.2014.04.040

Bicho N., Cascalheira J., Marreiros J. \& Pereira T. 2017. Rapid climatic events and long term cultural change: The case of the Portuguese Upper Paleolithic. Quaternary International 428: 3-16. https://doi.org/10.1016/j.quaint.2015.05.044

BiNFORD L. R. 1978. - Dimensional Analysis of Behavior and Site Structure: Learning from an Eskimo Hunting Stand. American Antiquity 43: 330-361. https://doi.org/10.2307/279390

BINFORD L. R. 1981. — Bones: ancient men and modern myths. Academic Press Inc., $320 \mathrm{p}$.

Blain H.-A. 2009. - Contribution de la paléoherpétofaune (Amphibia \& Squamata) à la connaissance de l'évolution du climat et du paysage du Pliocène supérieur au Pléistocène moyen d'Espagne. Treballs del Museu Geologic de Barcelona 16: 39-170.

Blain H.-A., BAilon S. \& CuenCA-Bescós G. 2008. — The EarlyMiddle Pleistocene palaeoenvironmental change based on the squamate reptile and amphibian proxies at the Gran Dolina site, Atapuerca, Spain. Palaeogeography, Palaeoclimatology, Palaeoecology 261: 177-192. https://doi.org/10.1016/j.palaeo.2008.01.015

Blain H.-A., Bailon S., Cuenca-Bescós G., Arsuaga J. L., Bermúdez De Castro J. M. \& Carbonell E. 2009. — Long-term climate record inferred from early-middle Pleistocene amphibian and squamate reptile assemblages at the Gran Dolina Cave, Atapuerca, Spain. Journal of Human Evololution 56: 55-65.

Blain H.-A., Lozano-Fernández I., Agustí J., Bailon S., Menéndez Granda L., Espígares Ortiz M. P., Ros-Montoya S., JimÉNEZ AREnas J. M., Toro-Moyano I., MartíneZ-Navarro B. \& SALA R. 2016. - Refining upon the climatic background of the Early Pleistocene hominid settlement in western Europe: Barranco León and Fuente Nueva-3 (Guadix-Baza Basin, SE Spain). Quaternary Science Reviews 144: 132-144. https://doi. org/10.1016/j.quascirev.2016.05.020

Blumenschine R. J. \& Selvaggio M. M. 1988. - Percussion marks on bone surfaces as a new diagnostic of hominid behaviour. Nature 333: 763-765. https://doi.org/10.1038/333763a0

BOËDA E. 1994. - Le concept Levallois: variabilité des méthodes. CNRS, Paris, 290 p.

Carbonell E., Guilbaud M. \& Mora R. 1983. - Utilización de la Lógica Analítica para el estudio de Tecno-complejos a cantos tallados, in Cahier Noir 1. C.R.P.E.S., Girona: 1-63.

Carbonell E., Mosquera M., Ollé A., Rodríguez ÁlvarezX. P. \& SALA R. 1992. - New elements of Logical Analytic System. First International Meeting onTechnical Systems to Configure Lithics Objects of scarce evolution, in Cahier Noir 6. C.R.P.E.S. Reial Societat Arqueològica Tarraconense, Girona, $61 \mathrm{p}$. 
Carrión-Santafé E., Baena-Preysler J., Conde-Ruiz C., CuarTERO F. \& ROCA M. 2008. - Variabilidad tecnológica en el musteriense de Cantabria. Treballs d'Arqueologia 14: 279-318.

Claud É., Deschamps M., Colonge D., Mourre V. \& Thiébaut C. 2015. - Experimental and functional analysis of late Middle Paleolithic flake cleavers from southwestern Europe (France and Spain). Journal of Archaeological Science 62: 105-127. https://doi. org/10.1016/j.jas.2015.05.013

Cuenca-Bescós G., Straus L. G., González Morales M. R. \& García Pimienta J. C. 2009. - The reconstruction of past environments through small mammals: from the Mousterian to the Bronze Age in El Mirón Cave (Cantabria, Spain). Journal of Archaeological Science 36: 947-955. https://doi.org/10.1016/j. jas.2008.09.025

CuENCA-Bescós G., Blain H.-A., Rofes J., LOZANO-FERnÁNDEZ I., López-GarCía J. M., Galán J. \& NúÑez-LahuerTa C. 2015. — Comparing two different Early Pleistocene microfaunal sequences from the caves of Atapuerca, Sima del Elefante and Gran Dolina (Spain): Biochronological implications and significance of the Jaramillo subchron. Quaternary International 389: 148-158. https://doi.org/10.1016/J.QUAINT.2014.12.059

Cunha P. P., Martins A. A., Buylaert J.-P., Murray S. A., Gouveia P. M., Font E., Pereira T., Figueiredo S., Ferreira C., Bridgland R. D., Yang P., Stevaux C. J. \& Mota R. 2019. - The Lowermost Tejo River Terrace at Foz do Enxarrique, Portugal: A Palaeoenvironmental Archive from $c .60-35 \mathrm{ka}$ and Its Implications for the Last Neanderthals in Westernmost Iberia. Quaternary 2 (1):3. https://doi.org/10.3390/quat2010003

Daffara S., Berruti G.-L. F., Caracausi S., RodríguezÁlvarez X.-P. \& Sala-Ramos R. 2018. — The use of "second rate" raw materials during Middle Palaeolithic. Technologi$\mathrm{cal}$ and functional analysis of two sites in north-eastern Iberia. L'Anthropologie 122: 626-653. https://doi.org/10.1016/j. anthro.2018.09.001

DE LA PeÑA Alonso P. 2015. - A Qualitative guide to recognize bipolar knapping for flint and quartz. Lithic Technology 40: 1-16.

De la Torre I., Martínez-Moreno J. \& Mora R. 2013. Change and Stasis in the Iberian Middle Paleolithic. Current Anthropology 54: S320-S336. https://doi.org/10.1086/673861

De Lombera Hermida A. 2005. - Aplicación del Sistema Lógico Analítico al estudio de un yacimiento gallego. La industria lítica de A Piteira (Toén, Ourense). Gallaecia 24: 7-33.

DE LOMBERA Hermida A. 2009. - The scar identification of lithic quartz industries, in STERNKE F., COSTA L.-J. \& EIGELAND L. (eds), Non-Flint Raw Material Use in Prehistory. Old Prejudices and New Direction. Proceedings of the XV World Congress of the U.I.S.P.P. BAR International Series (S1939). Archeopress, Oxford: 5-11.

DE Lombera-Hermida A. \& FÁbregas-ValCARCE R. (eds) 2013. Cova Eirós. Primeras evidencias de arte rupestre Paleolitico en el Noroeste Peninsular. Andavira Editora, Santiago de Compostela, 75 p.

de lombera Hermida A., Vaquero Rodríguez M., Alonso Fernández S., Rodríguez Álvarez X. P., LAZuén FernánDEZ T. \& FÁbregas-VAlCARCE R. 2008. - A cunca media no Mińo dentro das ocupacións paleolíticas do NW peninsular, in Méndez Quintas E. (ed.), Homenaxe a Xose María Álvarez Blázquez (2). Estudos Sobre Paleolítico. Instituto de Estudos Miñoranos, Gondomar: 321-346.

de Lombera Hermida A., Rodríguez Álvarez X. P., FábregasVAlCARCE R. \& MonCEL M. H. 2011. - La gestion du quartz au Pléistocène moyen et supérieur. Trois exemples d'Europe Méridionale. L'Anthropologie 115: 294-331.

de Lombera Hermida A., RodrígueZ-Álvarez X. P. \& FÁbregasVALCARCE R. 2014. - Cova Eirós archaeo-palaeontological site, Triacastela, Lugo., in SAla R., CARBOnell E., BermúdeZ DE Castro J. M. \& Arsuaga J. L. (eds), Pleistocene and Holocene Hunter-Gatherers in Iberia and the Gibraltar Strait: The Current Archaeological Record. Universidad de Burgos. Fundación Atapuerca, Burgos: 18-25. de Lombera-Hermida A., Díaz-Rodríguez M., Pérez Alberti A., Ameijenda-Iglesias A., Rodríguez-Álvarez X. P. \& FÁBrEGAS-VAlCARCE R. 2015. - Evolución de los patrones de asentamiento de los yacimientos paleolíticos de la Depresión de Monforte de Lemos (Lugo, Galicia). Sémata 27: 267-297.

De Lombera-Hermida A., Rodríguez-Rellán C. \& Vaqueiro Rodríguez M. 2016. - El sílex en el NW de la Península Ibérica. Un estado de la cuestión. Cuadernos de Prehistoria y Arqueología de Granada 26: 137-155.

Delagnes A. \& Rendu W. 2011. - Shifts in Neandertal mobility, technology and subsistence strategies in western France. Journal of Archaeological Science 38: 1771-1783. https://doi.org/10.1016/J. JAS.2011.04.007

DibBle H. L. 1987. - The Interpretation of Middle Paleolithic Scraper Morphology. American Antiquity 52: 109-117.

Díez J. C., Fernández-Jalvo Y., Rosell J. \& Cáceres I. 1999. Zooarchaeology and taphonomy of Aurora Stratum (Gran Dolina, Sierra de Atapuerca, Spain). Journal of Human Evololution 37: 623-652. https://doi.org/10.1006/jhev.1999.0346

Domingo L., Rodríguez-Gómez G., Libano I. \& GómezOlivencia A. 2017. - New insights into the Middle Pleistocene paleoecology and paleoenvironment of the Northern Iberian Peninsula (Punta Lucero Quarry site, Biscay): A combined approach using mammalian stable isotope analysis and trophic resource availability modeling. Quaternary Science Reviews 169: 243-262. https://doi.org/10.1016/j.quascirev.2017.06.008

DomíngueZ-Rodrigo M. \& Piqueras A. 2003. - The use of tooth pits to identify carnivore taxa in tooth-marked archaeofaunas and their relevance to reconstruct hominid carcass processing behaviours. Journal of Archaeological Science 30: 1385-1391. https://doi.org/10.1016/S0305-4403(03)00027-X

Duran J.-P. \& SOLER N. 2006. — Variabilité des modalités de débitage et des productions lithiques dans les industries moustériennes de la grotte de l'Arbreda, secteur alpha (Sernyà, Espagne). Bulletin de la Sociéte Préhistorique Française 103: 241-262.

Eren M. I., Roos C. I., STORY B. A., Von Cramon-Taubadel N. \& LYCETT S. J. 2014. - The role of raw material differences in stone tool shape variation: an experimental assessment. Journal of Archaeological Science 49: 472-487. https://doi.org/10.1016/j. jas.2014.05.034

Evans E. M. N., Van Couvering J. A. H. \& Andrews P. 1981. Palaeoecology of Miocene sites in Western Kenya. Journal of Human Evolution 10: 99-116. https://doi.org/10.1016/S00472484(81)80027-9

Fábregas-Valcarce R. \& De Lombera-Hermida A. 2010. - El Paleolítico superior en Galicia a la luz de las últimas investigaciones, in MAngado X. (ed.), Paleolitico Superior Peninsular. Novedades Del Siglo XXI. Homenaje Al Profesor Javier Fortea. Monografies SERP. Universitat de Barcelona, Barcelona: 255-270.

Fábregas-Valcarce R., De lombera Hermida A., Serna González M. R., Vaquero Rodríguez M., Pérez Rama M., Grandal D'Anglade A., Rodríguez Álvarez X. P., Alonso FERnÁNDEZ S. \& AMEIJENDA IgLESIAS A. 2012. — Ocupacións prehistóricas e históricas nas cavidades das Serras Orientais galegas. As covas de Eirós (Triacastela) e Valdavara (Becerreá). Gallaecia 31: 19-46.

Fábregas-Valcarce R., De lombera-Hermida A., Viñas Vallverdú R., Rodríguez Álvarez X. P. \& Soares Figueiredo S. 2015. - Throwing light on the hidden corners. New data on Palaeolithic art from NW Iberia, in Bueno-Ramírez P. \& Bahn P. (eds.), Prehistoric Art as Prehistoric Culture. Studies in Honour of Professor Rodrigo de Balbin-Behrmann. Archaeopress, Oxford: 171-181.

Faivre J.-P., Turq A., Bourguignon L., Cologne D., Jarry M. \& JAUBERT J. 2013. — Le Paléolithique moyen du Quercy : comportements techno-économiques et variabilité des productions lithiques, in Jarry M., BrugaL J.-P. \& Ferrier C. (eds), Modalité d'occupation et exploitation des milieux au Paléolithique dans le 
Sud-Ouest de la France : l'exemple du Quercy. Actes de La Session C67, XVème Congrès Mondial de l'UISPP, Lisbonne, Sept. 2006. Lisboa: 231-270.

FERNANDEZ-JALVO Y. \& ANDREWS P. 2016. - Atlas of taphonomic identifications: $1001+$ images of fossil and recent mammal bone modification. Springer Netherlands, 359 p.

Fernández-Jalvo Y., Díez J. C., Bermúdez De Castro J. M., CARbonell E. \& Arsuaga J. L. 1996. — Evidence of early cannibalism. Science 5247: 271-275. https://doi.org/10.1126/ science.271.5247.277

FERNÁNDEZ RodRÍGUEZ C. 2000. — Industia ósea prehistórica del Noroeste de la Península Ibérica. Lancia 4: 71-84.

FinLAYSON C. \& CARRIÓN J. S. 2007. — Rapid ecological turnover and its impact on Neanderthal and other human populations. Trends in Ecology \& Evolution 22: 213-222. https://doi. org/10.1016/J.TREE.2007.02.001

Finlayson J., Giles Pacheco F., Rodríguez Vidal J., Fa D., Gutiérrez lópez J. M., Pérez A., Finlayson G., Allué Martí E., Baena J., Cáceres Cuello De Oro I., Carrión J., Fernández Jalvo Y., Gleed-Owen C., Jimenez Espejo F., López P., López Sáez A., Riquelme Antal J. A., SÁnchez Marco A., Giles Guzmán F., Brown K., Fuentes N., Valarino C., Villalpando A., Stringer C. B., Martínez Ruiz F. \& SAKAMOTO T. 2006. - Late survival of neandertals at the southernmost extreme of Europe. Nature 05195: 850-853.

FleTCher W. J. \& SÁnchez Goñi M. F. 2008. - Orbital- and sub-orbital-scale climate impacts on vegetation of the western Mediterranean basin over the last 48,000 yr. Quaternary Research 70: 451-464. https://doi.org/10.1016/J.YQRES.2008.07.002

Fletcher W. J., SÁnchez GoÑi M. F., Allen J. R. M., Cheddadi R., Combourieu-Nebout N., Huntley B., LaWSON I., Londeix L., Magri D., Margari V., MÜller U. C., Naughton F., Novenko E., Roucoux K. \& Tzedakis P. C. 2010. - Millennial-scale variability during the last glacial in vegetation records from Europe. Quaternary Science Reviews 29: 2839-2864. https://doi.org/10.1016/j.quascirev.2009.11.015

FURIÓ M. 2007. — Los insectivoros (Soricomorpha, Erinaceomorpha, Mammalia) del Neógeno Superior del Levante Ibérico. Umpublished $\mathrm{PhD}$ thesis, Departament de Geologia. Universitat Autònoma de Barcelona, Barcelona, 341 p.

Garralda M. D., Galván B., Hernández C. M., Mallol C., GÓmez J. A. \& MAureille B. 2014. - Neanderthals from El Salt (Alcoy, Spain) in the context of the latest Middle Palaeolithic populations from the southeast of the Iberian Peninsula. Journal of Human Evolution 75: 1-15. https://doi.org/10.1016/j. jhevol.2014.02.019

González-Fortes G. G., Grandal-D’anglade A., Kolbe B., Fernandes D., Meleg I. N., García-Vázquez A., PintoLlona A. C., Constantin S., De Torres T. J., Ortiz J. E., Frischauf C., Rabeder G., Hofreiter M. \& Barlow A. 2016. - Ancient DNA reveals differences in behaviour and sociality between brown bears and extinct cave bears. Molecular Ecology 25: 4907-4918. https://doi.org/10.1111/mec.13800

Gutiérrez-Zugasti I., Rios-Garaizar J., Marín-Arroyo A. B., Rasines Del Río P., Maroto J., Jones J. R., Bailey G. N. \& RichARDS M. P. 2018. - A chrono-cultural reassessment of the levels VI-XIV from El Cuco rock-shelter: A new sequence for the Late Middle Paleolithic in the Cantabrian region (northern Iberia). Quaternary International 474: 44-55. https://doi. org/10.1016/j.quaint.2017.06.059

HARRISON S. P. \& SANCHEZ GOÑI M. F. 2010. - Global patterns of vegetation response to millennial-scale variability and rapid climate change during the last glacial period. Quaternary Science Reviews 29: 2957-2980. https://doi.org/10.1016/j.quascirev.2010.07.016

HAws J. 2012. - Neanderthal use of coastal wetlands during the last glacial/interglacial cycle in Portuguese Estremadura. Quaternary International 279-280: 190. https://doi.org/10.1016/j. quaint.2012.08.318
Haws J. A., Benedetti M. M., Funk C. L., Bicho N. F., Daniels J. M., Hesp P. A., Minckley T. A., Forman S. L., Jeraj M. Gibaja J. F. \& Hоскетt B. S. 2010. - Coastal wetlands and the Neanderthal settlement of Portuguese Estremadura. Geoarchaeology 25: 1-36. https://doi.org/10.1002/gea.20330

Haws J. A., Benedetti M. M., Talamo S., Bicho N., Cascalheira J., Grace Ellis M., Carvalho M. M., Friedl L., Pereira T. \& Zinsious B. K. 2020. - The early Aurignacian dispersal of modern humans into westernmost Eurasia. Proceedings of the National Academy Science of the United States of America 117: 25414-25422. https://doi.org/10.1073/pnas.2016062117

HERNÁNDEZ FERNÁNDEZ M. 2001. — Bioclimatic discriminant capacity of terrestrial mammal faunas. Global Ecology and Biogeography 10: 189-204. https://doi.org/10.1046/j.1466-822x.2001.00218.x

Hernández Fernández M., Álvarez Sierra M. Á. \& PeláezCAMPOMANES P. 2007. - Bioclimatic analysis of rodent palaeofaunas reveals severe climatic changes in Southwestern Europe during the Plio-Pleistocene. Palaeogeography. Palaeoclimatology. Palaeoecology 251: 500-526. https://doi.org/10.1016/j.palaeo.2007.04.015

Higham T., Jacobi R., Basell L., Ramsey C. B., Chiotti L. \& Nespoulet R. 2011. - Precision dating of the Palaeolithic: A new radiocarbon chronology for the Abri Pataud (France), a key Aurignacian sequence. Journal of Human Evolution 61: 549-563.

Higham T., Douka K., Wood R., Ramsey C. B., Brock F., Basell L., Camps M., Arrizabalaga A., Baena J., BarrosoRuiz C., Bergman C., Boitard C., Boscato P., Caparros M., Conard N. J., Draily C., Froment A., Galvan B., Gambassini P., Garcia-Moreno A., Grimaldi S., Haesaerts P., Holt B., Iriarte-Chiapusso M.-J., JelineK A., Jorda Pardo J. F., Maillo-Fernandez J.-M., Marom A., Maroto J., Menendez M., Metz L., Morin E., Moroni A., Negrino F., Panagopoulou E., Peresani M., Pirson S., De la Rasilla M., Riel-Salvatore J., Ronchitelli A., Santamaria D., Semal P., Slimak L., Soler J., Soler N., Villaluenga A., Pinhasi R. \& JACOBI R. 2014. - The timing and spatiotemporal patterning of Neanderthal disappearance. Nature 512: 306-309. https:// doi.org/10.1038/nature13621

Hillson S. 2016. - Mammal bones and teeth: an introductory guide to methods of identification. Routledge, New York, $132 \mathrm{p}$.

Hodgkins J., Marean C. W., Turq A., Sandgathe D., McPherRON S. J. P. \& DibBle H. 2016. - Climate-mediated shifts in Neandertal subsistence behaviors at Pech de l'Azé IV and Roc de Marsal (Dordogne Valley, France). Journal of Human Evolution 96: 1-18. https://doi.org/10.1016/j.jhevol.2016.03.009

Hopkinson T., Nowell A. \& White M. J. 2013. — Life Histories, Metapopulation Ecology, and Innovation in the Acheulian. PaleoAnthropology: 61-76. https://doi.org/10.1038/nature13621

JAUBerT J. 1997. — L'Utilisation du Quartz au Paléolithique Inférieur et Moyen, in Bracco J.-P. (ed.), Préhistoire Anthropoligie Méditerranéennes. L'exploitation du quartz au Paléolithique. Premier Table Ronde. Aix-En-Provence 18-19 Avril 1996. CNRS, Paris: 239-259.

Jöris O. \& STREET M. 2008. - At the end of the 14C time scalethe Middle to Upper Paleolithic record of western Eurasia. Journal of Human Evolution 55: 782-802. https://doi.org/10.1016/j. jhevol.2008.04.002

KLARIC L. 2009. - Les systèmes de production de supports d'armatures et leur place dans la gestion des ressources lithiques: une voie privilégiée pour la compréhension des societés gravettiennes de la Vallée du Côa, in AUBRY T. (ed.), 200 Séculos Da História Do Vale Do Côa: Incursoes Na Vida Quotidiana Dos Caçadores-Artistas Do Paleolitico. IGESPAR, IP, Lisboa: 247-255.

Klein R. G., Wolf C., Freeman L. G. \& Allwarden K. 1981. The use of dental crown heights for constructing age profiles of red deer and similar species in archaeological samples. Journal of Archaeological Science 8: 1-31. https://doi.org/10.1016/03054403(81)90010-8 
KuHN S. L. 1992. — On Planning and Curated Technologies in the Middle Paleolithic. Journal of Anthropological Research 48: 185-214.

Laplace G. \& Saenz de Buruaga A. 2000. - Application de la Typologie Analythique et Structurale à l'étude de l'outillage moustéroïde de l'Abri Olha 2 à Cambo (Kambo) en Pays Basque. Paleo 12: 261-324.

Lazuén Fernández T., Fábregas-Valcarce R., De Lombera Hermida A. \& Rodríguez Álvarez X. P. 2011. — La gestión del utillaje de piedra tallada en el Paleolítico medio de Galicia. El nivel 3 de Cova Eirós. Trabajos de Prehistoria 68: 237-258.

Llana Rodríguez C., Villar Quinteiro R. \& Martínez CORTIZAS A. 1996. - Secuencia paleoambiental y cultural de la cueva de A Valiña (Castroverde, Lugo): Una ocupación chatelperroniense en Galicia, in Pérez Alberti A., MARTinI P., Chesworth W. \& Martínez Cortizas A. (eds), Dinámica y Evolución de Medios Cuaternarios. Xunta de Galicia, Santiago de Compostela: 97-112.

LÓPEZ-GARCÍA J. M. 2008. - Evolución de la diversidad taxonómica de los micromamíferos en la Peninsula Ibérica y cambios Paleoambientales durante el Pleistoceno Superior. Umpublished PhD thesis, Departament d'Història i Història de l'Art. Universitat Rovira i Virgili, Tarragona, $407 \mathrm{p}$.

LÓpez-García J. M. 2011. - Los micromamíferos del Pleistoceno superior de la Peninsula Ibérica. Evolución de la diversidad taxonómica y cambios paleoambientales y paleoclimáticos, Departament d'Història i Història de l'Art. Editorial Académica Española, Saarbrücken, 416 p.

lópez-García J. M., Blain H., Cuenca Bescós G., Alonso C., Alonso Fernández S. \& VAquero Rodríguez M. 2011. Small vertebrates (Amphibia, Squamata, Mammalia) from the late Pleistocene-Holocene of the Valdavara-1 cave (Galicia, northwestern Spain). Geobios 44: 253-269. https://doi.org/10.1016/j. geobios.2010.10.001

Maíllo Fernández J. M. 2008. - El Chatelperroniense en el Noroeste de la Península Ibérica. Férvedes 5: 127-136.

Mallol C., Hernández C. M. \& Machado J. 2012. - The significance of stratigraphic discontinuities in Iberian Middleto-Upper Palaeolithic transitional sites. Quaternary International 275: 4-13. https://doi.org/10.1016/j.quaint.2011.07.026

Marín-Arroyo A. B., Rios-Garaizar J., Straus L. G., Jones J. R., De la Rasilla M., González Morales M. R., Richards M., Altuna J., Mariezkurrena K. \& Ocio D. 2018. Chronological reassessment of the Middle to Upper Paleolithic transition and Early Upper Paleolithic cultures in Cantabrian Spain. PLoS ONE 13: e0194708. https://doi.org/10.1371/ journal.pone. 0194708

Marín-Arroyo A. B., Geiling J.-M., Jones J. R., González Morales M. R., Straus L. G. \& Richards M. P. 2020 - The Middle to Upper Palaeolithic transition at El Mirón cave (Cantabria, Spain). Quaternary International 544: 23-31. https://doi. org/10.1016/j.quaint.2018.06.036

Maroto J., Vaquero M., Arrizabalaga Á., BaEna J., Baquedano E., Jordá J., Juliá R., Montes R., Van Der Plicht J., Rasines P. \& Wood R. 2012. - Current issues in late Middle Palaeolithic chronology: New assessments from Northern Iberia. Quaternary International 247: 15-25. https://doi.org/10.1016/j. quaint.2011.07.007

Márquez B., Baquedano E., Pérez-González A. \& Arsuaga J. L. 2017. - Denticulados, muescas: :para qué sirven? Estudio funcional de una muestra musteriense en cuarzo del Abrigo de Navalmaíllo (Pinilla del Valle, Madrid, España). Trabajos de Prehistoria 74: 26-46. https://doi.org/10.3989/tp.2017.12182

Martín Seijo M. 2013. - A Xestión do bosque e do monte dende a Idade de Ferro á época romana no noroeste da peninsula ibérica. Consumo de combustibles e produción de manufacturas en madeira. Umpublished PhD thesis, Departamento de Historia, Universidade de Santiago de Compostela, Santiago de Compostela, $709 \mathrm{p}$.
Martínez-Moreno J., Mora R. \& Ignacio De La T. 2010. The Middle-to-Upper Palaeolithic transition in Cova Gran (Catalunya, Spain) and the extinction of Neanderthals in the Iberian Peninsula. Journal of Human Evolution 58: 211-226. https://doi.org/10.1016/j.jhevol.2009.09.002

Martínez Cortizas A. \& Llana Rodríguez C. 1996. - Morphostructural variables and the analysis of their effect on quartz blank characteristics, in Moloney N., Raposo L. \& Santonja M. (eds), Non-Flint Stone Tools and the Palaeolithic Occupation of the Iberian Peninsula. Tempus Reparatum, Oxford: 49-53.

Matias H. 2016. - Raw material sourcing in the Middle Paleolithic site of Gruta da Oliveira (Central Limestone Massif, Estremadura, Portugal). Journal of Lithic Studies 3. https://doi. org/10.2218/jls.v3i2.1452

Melchionna M., Di Febbraro M., Carotenuto F., Rook L., Mondanaro A., Castiglione S., Serio C., Vero V. A., Tesone G., Piccolo M., Diniz-Filho J. A. F. \& Raia P. 2018. Fragmentation of Neanderthals' pre-extinction distribution by climate change. Palaeogeography, Palaeoclimatology, Palaeoecology 496: 146-154. https://doi.org/10.1016/j.palaeo.2018.01.031

Menendez M., Álvarez-Alonso D., De Andrés-Herrero M., Carral P., García Sánchez E. M. Quesada J. \& Rojo J. 2017. - The Middle to Upper Paleolithic transition in La Güelga cave (Asturias, Northern Spain). Quaternary International 474: 71-84. https://doi.org/10.1016/j.quaint.2017.08.061

Mourre V. 1996. - Les industries en Quartz au Paleolithique. Terminologie, Methodologie et Technologie. Paleo 8: 205-223.

Mourre V. 2003. — Discoïde ou pas Discoïde ? Réflexions sur la pertinence des critères techniques définissant le débitage Discoïde, in Peresani M. (ed.), Discoid Lithic Technology. Advances and Implications. Archaeopress (BAR International Series 1120), Oxford: 1-18.

Oliva M., Palacios D., Fernández-Fernández J. M., RodRígueZ-Rodríguez L., GarCÍA-RUIZ J. M., ANDRÉS N., CARrasco R. M., Pedraza J., Pérez-Alberti A., Valcárcel M. \& Hughes P. D. 2019. - Late Quaternary glacial phases in the Iberian Peninsula. Earth-Science Reviews 192: 564-600. https:// doi.org/10.1016/j.earscirev.2019.03.015

Palombo M. \& Sardella R. 2007. - Biochronology and biochron boundaries: A real dilemma or a false problem? Quaternary International 160: 30-42

PARgeter J. 2016. - Lithic miniaturization in Late Pleistocene southern Africa. Journal of Archaeologial Science: Reports 10: 221236. https://doi.org/10.1016/J.JASREP.2016.09.019

Pelegrin J., Karlin C. \& Bodu P. 1988. — Chaînes opératoires: un outil pour le préhistorien., in TIXIER J. (ed.), Technologie Préhistorique. CNRS, Paris: 55-62.

Pérez Alberti A., Díaz M. V, Martini I. P., Pascucci V. \& ANDREUCCI S. 2011. - Upper Pleistocene glacial valley-junction sediments at Pias, Trevinca Mountains, NW Spain, in MARTINI I. P., French H. M. \& Pérez Alberti A. (eds), Ice-Marginal and Periglacial Processes and Sediments. Geological Society, Special publication. No. 354., London: 93-110.

Ramil-Rego P., Iriarte M. J., Muñoz Sobrino C. \& Gómez Orellana L. 2005. - Cambio climático y dinámica temporal del paisaje y de los hábitats en las ecorregiones del NW de la Península Ibérica durante el Pleistoceno superior. Munibe 57: 537-551.

Ramil-Rego P., Gómez-Orellana L. \& Muñoz Sobrino C. 2010. - Cambio climático durante el último ciclo glaciar-interglaciar en el NW Ibérico, in BeTtenCourt A., IsABEL A. M. \& Monteiro-Rodrigues S. (eds), Variaçóes Paleoambientais e Evoluçáo Antrópica No Quaternário Do Ocidente Peninsular. APEQ - Associação Portuguesa para o Estudo do Quaternário C I TCEM - Centro de Investigaçáo Transdisciplinar "Cultura, Espaço e Memória”: 23-38.

RAMSEY C. B. 2009. - Bayesian analysis of radiocarbon dates. Radiocarbon 51 (1):337-360. https://doi.org/10.2458/azu_js_rc.v51i1.3494 
Reimer P. J., Bard E., Bayliss A., Beck J. W., Blackwell P. G., RamSEy C. B., Buck C. E., Cheng H., Edwards R. L., Friedrich M., Grootes P. M., Guilderson T. P., Haflidason H., Hajdas I., Hatté C., Heaton T. J., Hoffmann D. L., Hogg A. G., Hughen K. A., Kaiser K. F., Kromer B., Manning S. W., Niu M., Reimer R. W., Richards D. A., Scott E. M., SouTHON J. R., STAFF R. A., TURney C. S. M. \& VAN DER Plicht J. 2016. - IntCal13 and Marine13 Radiocarbon Age Calibration Curves 0-50,000 Years cal BP. Radiocarbon 55 (4): 1869-1887. https://doi.org/10.2458/azu_js_rc.55.16947

Rey-Rodríguez I., LÓPEZ-GarCÍA J.-M., BenNÀSAR M., BaÑulsCardona S., Blain H.-A., Blanco-Lapaz Á., RodríguezÁlvarez X.-P., De Lombera-Hermida A., Díaz-Rodríguez M., Ameijenda-Iglesias A., Agustí J. \& Fábregas-Valcarce R. 2016. - Last Neanderthals and first Anatomically Modern Humans in the NW Iberian Peninsula: Climatic and environmental conditions inferred from the Cova Eirós small-vertebrate assemblage during MIS 3. Quaternary Science Reviews 151: 185197. https://doi.org/10.1016/j.quascirev.2016.08.030

Rios Garáizar J. 2008. - Variabilidad tecnológica en el Paleolítico Medio de los Pirineos Occidentales: una expresión de las dinámicas históricas de las sociedades neandertales. Treballs d'Arqueologia 14: 171-194.

RIOS-GARÁIZAR J. 2012. — Industria lítica y sociedad del paleolítico medio y superior en torno al Golfo de Bizkaia. PubliCan Edciones. Ediciones Universidad de Cantabria, Santander, 561 p.

Rodríguez-Álvarez X. P., FÁbregas-Valcarce R., LazuéN Fernández T., De lombera Hermida A., Pérez Alberti A., Peña Alonso J. A., Rodríguez Rellán C., Terradillos Bernal M., Ameijenda A. \& Rodríguez Álvarez E. 2008. Nuevos yacimientos paleolíticos en la Depresión de Monforte de Lemos (Lugo, Galicia, España). Revista de Cuaternario y Geomorfología 22: 71-92.

Rodríguez-Allvarez X. P., De lombera Hermida A., FábregasValcarce R. \& Lazuén Fernández T. 2011. - The Upper Pleistocene site of Cova Eirós (Triacastela, Lugo, Spain), in de Lombera Hermida A. \& FÁbregas-Valcarce R. (eds), To the West of Spanish Cantabria: The Palaeolithic Settlement of Galicia. Archaeopress (BAR International series 2283), Oxford: 123-133.

RODRÍGUEZ-RELLÁN C. 2016. - Variability of the rebound hardness as a proxy for detecting the levels of continuity and isotropy in archaeological quartz. Quaternary International 424: 69-83. https://doi.org/10.1016/j.quaint.2015.12.085

Romandini M., Terlato G., Nannini N., Tagliacozzo A., BenazZi S. \& Peresani M. 2018. - Bears and humans, a Neanderthal tale. Reconstructing uncommon behaviors from zooarchaeological evidence in southern Europe. Journal of Archaeological Science 90: 71-91. https://doi.org/10.1016/j.jas.2017.12.004

Rosell ARdèvol J. 2001. - Patrons d'aprofitament de les biomasses animals durant el Pleistocè inferior i mig (Sierra de Atapuerca, Burgos) i Superior (Abric Romani, Barcelona). Umpublished PhD thesis, Área Prehistoria. Univesitat Rovira i Virgili, Tarragona.

Rosell J., Blasco R., Rivals F., Chacón G., Menéndez M., Morales J. I., Rodríguez-Hidalgo A., Cebriá A., CarBONELL E. \& SERRAT D. 2010. - A stop along the way: the role of Neanderthal groups at Level III of Teixoneres cave (Moià, Barcelona, Spain). Quaternaire 21: 139-154.

Rosell J., Blasco R., Arilla M., Camarós E., Rufà A., SÁnchezHernández C., Picin A., Andrés M., Blain H.-A., LópezGarcía J. M., Iriarte E. \& Cebrià A. 2017. - A resilient landscape at Teixoneres Cave (MIS 3; Moià, Barcelona, Spain): The Neanderthals as disrupting agent. Quaternary International 435: 195-210. https://doi.org/10.1016/J.QUAINT.2015.11.077

Roucoux K. H., De Abreu L., SACKLeton N. J. \& Tzedakis P. C. 2005. - The response of NW Iberian vegetation to North Atlantic climate oscillations during the last 65 kyr. Quaternary Science Reviews 24: 1637-1653.
SÁnchez Goñi M. F., Landais A., Fletcher W. J., Naughton F., Desprat S. \& DupraT J. 2008. - Contrasting impacts of Dansgaard-Oeschger events over a western European latitudinal transect modulated by orbital parameters. Quaternary Science Reviews 27: 1136-1151. https://doi.org/10.1016/j.quascirev.2008.03.003

Sanchis A., Real C., Sauqué V., Núñez-Lahuerta C., Égüez N., Tormo C., Pérez Ripoll M., Carrión Marco Y., Duarte E. \& De La Rasilla M. 2019. - Neanderthal and carnivore activities at Llonin Cave, Asturias, northern Iberian Peninsula: Faunal study of Mousterian levels (MIS 3). Comptes Rendus Palevol 18: 113-141. https://doi.org/10.1016/j.crpv.2018.06.001

Santamaría Álvarez D. \& De La Rasilla Vives M. 2013. Datando el final del Paleolítico medio en la Península Ibérica. Problemas metodológicos y límites de la interpretación. Trabajos de Prehistoria 70: 241-263.

SCHMidT I. \& ZimmermanN A. 2019. — Population dynamics and socio-spatial organization of the Aurignacian: Scalable quantitative demographic data for western and central Europe. PLoS ONE 14: e0211562.

Sevilla P. 1988. - Estudio paleontológico de los Quirópteros del Cuaternario español. Paleontologia i Evolució 22: 113-233.

SHIPMAN P. \& ROSE J. 1983. - Early hominid hunting, butchering, and carcass-processing behaviors: Approaches to the fossil record. Journal of Anthropological Archaeology 2: 57-98. https:// doi.org/10.1016/0278-4165(83)90008-9

Shipman P., Foster G. \& Schoeninger M. 1984. - Burnt bones and teeth: an experimental study of color, morphology, crystal structure and shrinkage. Journal of Archaeological Science 11: 307-325. https://doi.org/10.1016/0305-4403(84)90013-X SteELMAN K. L., DE LOMBERA-HERmida A., Viñas-VALLVERdú R. Rodríguez-Álvarez X. P., Carrera-Ramírez F., Rubio-Mora A. \& FÁbregas-VAlCARCE R. 2017. — Cova Eirós: An integrated approach to dating the earliest known cave art in NW Iberia. Radiocarbon 59 (1): 151-164. https://doi.org/10.1017/RDC.2017.4

STRAus L. 2005. - A mosaic of change: the Middle-Upper Paleolithic transition as viewed from New Mexico and Iberia. Quaternary International 137: 47-67. https://doi.org/10.1016/J. QUAINT.2004.11.019

STRAUS L. G. 2012. - The emergence of modern-like forager capacities \& behaviors in Africa and Europe: Abrupt or gradual, biological or demographic? Quaternary International 247: 350357. https://doi.org/10.1016/J.QUAINT.2010.10.002

Tardy N., Vosges J. \& VAROUTSIKOS B. 2016. — Micro-blade production on hyaline quartz during the Late Neolithic of northern Greece (5400-4600 cal. B.C.): Examples from Dikili Tash and Promachonas-Topolniča. Quaternary International 424: 212-231. https://doi.org/10.1016/j.quaint.2015.11.139

Tejero J.-M., Yeshurun R., Barzilai O., Goder-Goldberger M., Hershkovitz I., Lavi R., Schneller-Pels N. \& Marder O. 2016. - The osseous industry from Manot Cave (Western Galilee, Israel): Technical and conceptual behaviours of bone and antler exploitation in the Levantine Aurignacian. Quaternary International 403: 90-106. https://doi.org/10.1016/J.QUAINT.2015.11.028

Terradillos-Bernal M. \& Díez-Fernández-Lomana J.-C. 2012. - La transition entre les Modes 2 et 3 en Europe : le rapport sur les gisements du Plateau Nord (Péninsule Ibérique). L'Anthropologie 116: 348-363. https://doi.org/10.1016/j. anthro.2012.06.001

Thiébaut C., Mourre V., Chalard P., Colonge D., CoudenNEAU A., DESChAMPS M. \& SACCO-SONADOR A. 2012. — Lithic technology of the final Mousterian on both sides of the Pyrenees. Quaternary International 247: 182-198. https://doi.org/10.1016/j. quaint.2011.05.028

Turq A., Roebroeks W., Bourguignon L. \& Faivre J.-P. 2013. - The fragmented character of Middle Palaeolithic stone tool technology. Journal of Human Evolution 65: 641-655. https:// doi.org/10.1016/j.jhevol.2013.07.014 
VALVERDE I. 2019. — Patrones de aprovechamiento faunistico y estrategias de subsistencia durante la transición Paleolitico medio-superior en el NO peninsular. Umpublished $\mathrm{PhD}$ thesis, Universidade de Santiago de Compostela. Universitá degli Studi di Ferrara, Santiago de Compostela, 339 p.

Vaquero M., Maroto J., ArRIZABÁlaga Á., BaEna J., Baquedano E., Carrión E., Jordá J., Martinón-Torres M., Menéndez M., Montes BARQuín R. \& Rosell ARdèVol J. 2006. — The Neanderthal-Modern Human meeting in Iberia: A critical view of the cultural geographical and chronological data, in CONARD N. J. (ed.), When Neanderthals and Modern Humans Met. Kerns Verlag, Tübingen: 419-439.

Vaquero M., Van Der Made J., Blain H. A., Ibáñez N., LópezGarcía J. M., Rivals F., Alonso S., Ameijenda A., BennÀsar M., Fernández-García M., De Lombera-Hermida A. \& VALVERDE I. 2018. - Fauna, environment and human presence during MIS5 in the North of Spain: The new site of Valdavara 3. Comptes Rendus Palevol 17: 557-593. https://doi.org/10.1016/j. crpv.2018.03.004

VAqUero Rodríguez M. 2006. - El tránsito Paleolítico Medio/ Superior en la Península Ibérica y la Frontera del Ebro: comentario a Zilhao (2006). Pyrenae 37: 107-129.

Viana-Soto A. \& PéReZ-Albberti A. 2019. - Periglacial deposits as indicators of paleotemperatures. A case study in the Iberian Peninsula: The mountains of Galicia. Permafrost and Periglacial Processes 30: 374-388. https://doi.org/10.1002/ppp.2026

Villar QuinTEIRo R. 1997. - El Paleolítico Superior y Epipaleolítico en Galicia. Zephyrus 50: 71-106.

Wood R. E., Arrizabalaga A., Camps M., Fallon S., IriarteChiapusso M. J., Jones R., Maroto J., De La Rasilla M., Santamaría D., Soler J., Soler N., Villaluenga A. \& Higham T. F. G. 2014. — The chronology of the earliest Upper
Palaeolithic in northern Iberia: New insights from L'Arbreda, Labeko Koba and La Viña. Journal of Human Evolution 69: 91-109. https://doi.org/10.1016/j.jhevol.2013.12.017

WoOd R., BERnAldo DE Quirós F., MAÍllo-FERnÁNDEZ J.-M., Tejero J.-M., Neira A. \& Higham T. 2016. — El Castillo (Cantabria, northern Iberia) and the Transitional Aurignacian: Using radiocarbon dating to assess site taphonomy. Quaternary International 474: 56-70. https://doi.org/10.1016/j.quaint.2016.03.005

WRAGG SYKES R. M. 2015. - To see a world in a hafted tool: birch pitch composite technology, cognitionand memoryin Neanderthals, in Coward F., Wenban-Smith F., Pope M. \& Hosfield R. (eds), Settlement, Society and Cognition in Human Evolution: Landscapes in Mind. Cambridge University Press, Cambridge: 117-137. https://doi.org/10.1017/CBO9781139208697.008

ZILHĀO J. 2000. - The Ebro Frontier: A Model for the Late Extinction of Iberian Neanderthals, in STRINGER C. B., BARTON R. N. \& Finlayson J. (eds.), Neanderthals on the Edge. Oxbow Books, Oxford: 111-121.

ZILHÃO J. 2006. - Chronostratigraphy of the Middle-to-Upper Paleolithic Transition in the Iberian Peninsula. Pyrenae 37: 7-84.

Zilhâo J., Davis S. J. M., Duarte C., Soares A. M. M., Steier P. \& WiLD E. 2010. - Pego do Diabo (Loures, Portugal): Dating the Emergence of Anatomical Modernity in Westernmost Eurasia. PLoS One 5: e8880. https://doi.org/10.1371/journal. pone. 0008880

Zilhão J., Anesin D., Aubry T., Badal E., Cabanes D., Kehl M., Klasen N., Lucena A., Martín-Lerma I., Martínez S., Matias H., Susini D., Steier P., Wild E. M., Angelucci D. E., Villaverde V. \& Zapata J. 2017. — Precise dating of the Middle-to-Upper Paleolithic transition in Murcia (Spain) supports late Neandertal persistence in Iberia. Heliyon 3: e00435. https://doi.org/10.1016/j.heliyon.2017.e00435 